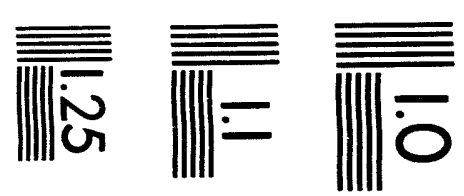

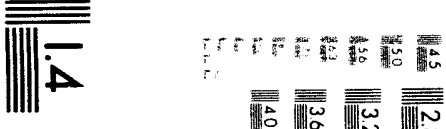

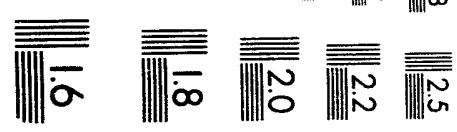



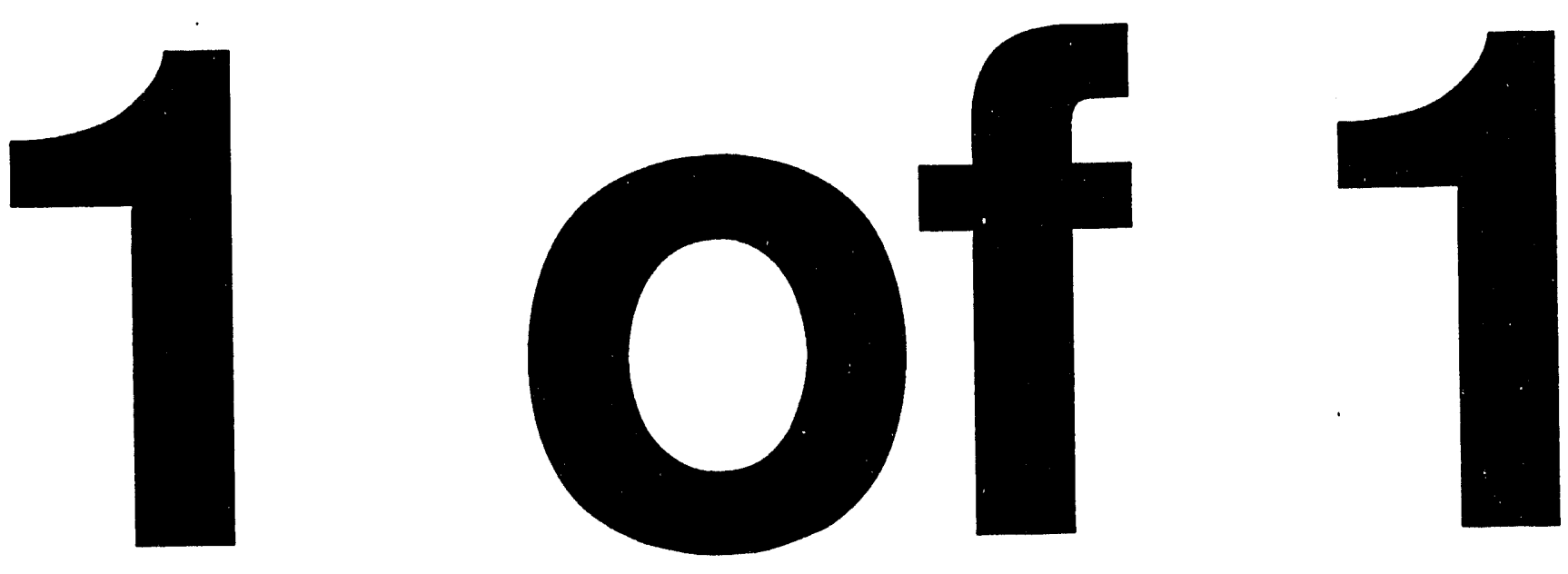
Radionuclides, Inorganic Constituents, Organic Compounds, and Bacteria in Water From Selected Wells and Springs From the Southern Boundary of the Idaho National Engineering Laboratory to the Hagerman Area, Idaho, 1991

By Roy C. Bartholomay and Daniel D. Edwards, U.S. Geological Survey and

Linford J. Campbell, Idaho Department of Water Resources

\section{U.S. GEOLOGICAL SURVEY}

Open-File Report 93-102

Prepared in cooperation with the

U.S. DEPARTMENT OF ENERGY

and

IDAHO DEPARTMENT OF WATER RESOURCES

Idaho Falls, Idaho

1993

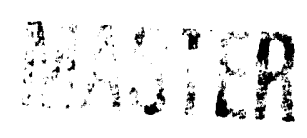




\section{U.S. DEPARTMENT OF THE INTERIOR \\ BRUCE BABBITT, Secretary}

U.S. GEOLOGICAL SURVEY

Dallas L. Peck, Director

For additional information write to:

Copies of this report can be purchased from:

Project Chief

U.S. Geological Survey

INEL, MS 4148

P.O. Box 2230

Idaho Falls, ID 83403
U.S. Geological Survey

Books and Open-File Reports Section

Box 25425

Federal Center

Denver, CO 80225 


\section{CONTENTS}

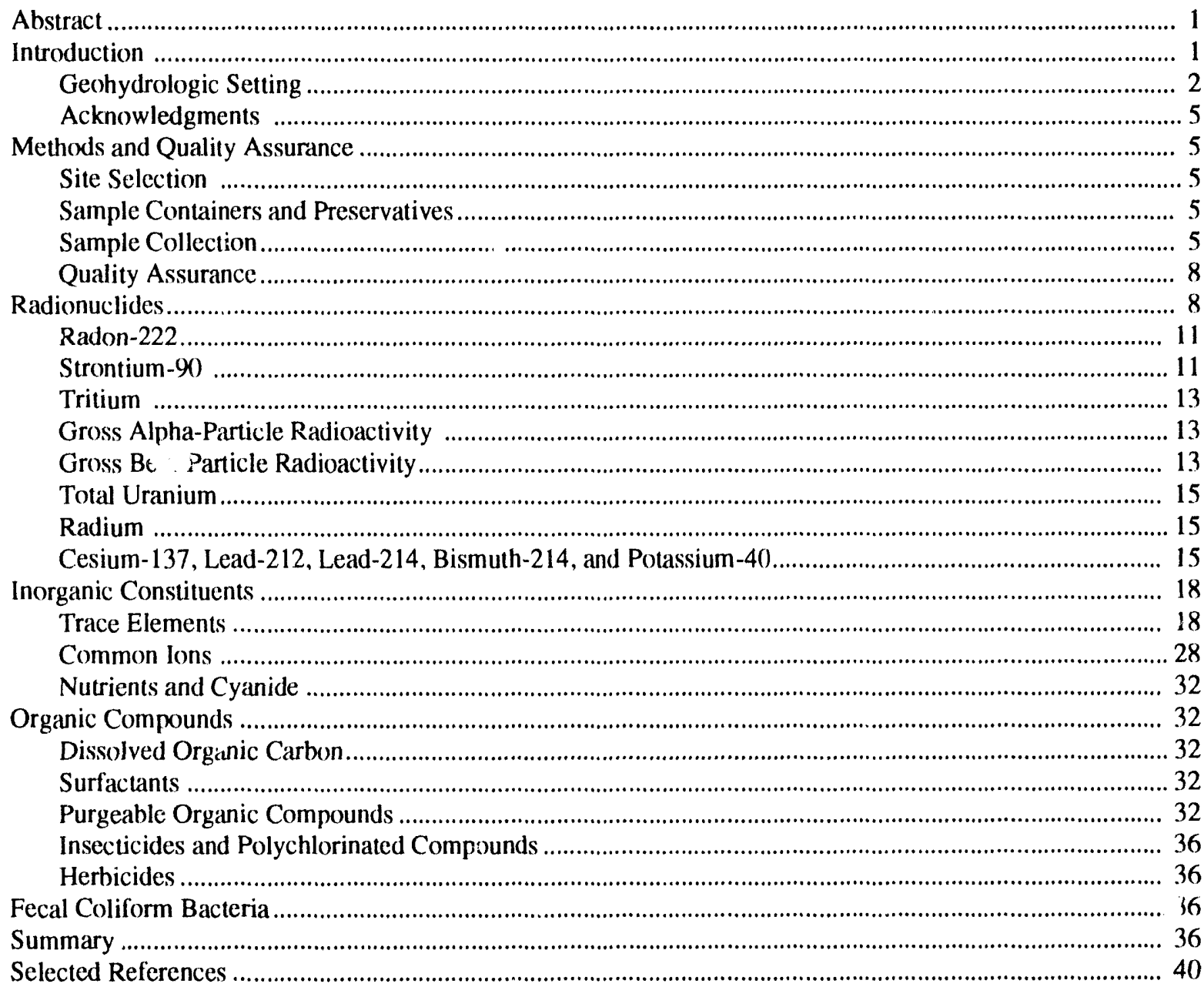

\section{FIGURES}

1 and 2: Maps showing:

1. Location of the study area between the Idaho National Engineering Laboratory and Hagerman, Idaho 3

2. Location of selected water-quality sampling sites on the eastern Snake River Plain......................... 4

\section{TABLES}

1. Containers and preservatives used for water-sample collection

2. Results of field measurements of water for $\mathrm{pH}$, specific conductance, temperature, alkalinity, and concentrations of dissolved oxygen from selected wells and springs, eastern Snake River Plain ................. 9

3. Maximum contaminant levels for types of radioactivity and selected radionuclides in drinking water

4. Concentrations of radon-222, strontium-90, and tritium in water from selected wells and springs, eastern Snake River Plain

5. Concentrations of gross alpha-particle radioactivity in water from selected wells and springs, eastern Snake River Plain. 
6. Concentrations of gross beta-particle radioactivity in water from selected wells and springs, eastern Snake River Plain

7. Concentrations of total uranium and selected radium isotopes in water from selected wells and springs, eastern Snake River Plain

8. Concentrations of cesium-137, lead-212, lead-214, hismuth-214, and potassium-40 in

water from selected wells and springs, eastern Snake River Plain..

9. Maximum contaminant levels and reporting levels of selected trace elements in drinking water..............20

10. Concentrations of dissolved trace elements in water from selected wells and springs, eastern Snake River Plain

11. Concentrations of total trace elements in water from selected wells and springs, eastern Snake River Plain.

12. Maximum contaminant levels and reporting levels of selected common ions in drinking water

13. Concentrations of dissolved common ions in water from selected wells and springs, eastern Snake River Plain.

14. Concentrations of total common ions in water from selected wells and springs, eastern Snake River Plain.

15. Maximum contaminant levels and reporting levels for selected nutrients, cyanide, dissolved organic carbon, and surfactants in drinking water

16. Concentrations of nutrients, cyanide, dissolved organic carbon, and surfactants in water from selected wells and springs, eastern Snake River Plain

17. Maximum contaminant levels and reporting levels of selected purgeable organic compounds in drinking water.

18. Maximum contaminant levels and reporting levels of selected insecticides and gross polychlorinated compounds in drinking water.

19. Maximum contaminant levels and reporting levels of triazines and chlorophenoxy-acid herbicides in drinking water.

\section{CONVERSION FACTORS AND ABBREVIATED UNITS}

\begin{tabular}{rcl} 
Multiply & By & To Obtain \\
\hline acre-foot per year (acre-ft/yr) & 1,233 & cubic meter per year \\
foot $(\mathrm{ft})$ & 0.3048 & meter \\
gallon $(\mathrm{gal})$ & 3.785 & liter \\
mile $(\mathrm{mi})$ & 1.609 & kilometer \\
millirem per year (mrem/yr) & 0.010 & millisievert per year \\
picocurie per liter $(\mathrm{pCi} / \mathrm{L})$ & 0.037 & becquerel per liter \\
square mile $\left(\mathrm{mi} \mathrm{i}^{2}\right)$ & 2.590 & square kilometer
\end{tabular}

Temperature can be converted from degrees Celsius $\left({ }^{\circ} \mathrm{C}\right)$ to degrees Fahrenheit $\left({ }^{\circ} \mathrm{F}\right)$ by the equation: $\quad$ " $F=(" \mathrm{C} \times 1.8)+32$

Abbreviated units used in report: gram (g); milliliter $(\mathrm{mL})$; liter $(\mathrm{L})$; microgram per liter $(\mu \mathrm{g} / \mathrm{L})$; milligram per liter (mg/L); micrometer $(\mu \mathrm{m})$; and microsiemens per centimeter at 25 degrees celsius $(\mu \mathrm{S} / \mathrm{cm})$. 


\title{
Radionuclides, Inorganic Constituents, Organic Compounds, and Bacteria in Water from Selected Wells and Springs from the Southern Boundary of the Idaho National Engineering Laboratory to the Hagerman Area, Idaho, 1991
}

\author{
by Roy C. Bartholomay and Daniel D. Edwards, U.S. Geological Survey \\ Linford J. Campbell, Idaho Department of Water Resources
}

\begin{abstract}
The U.S. Geological Survey and the Idaho Department of Water Resources, in response to a request from the U.S. Department of Energy, sampled 18 sites as part of a long-term project to monitor water quality of the Snake River Plain aquifer from the southern boundary of the Idaho National Engineering Laboratory to the Hagerman area. Water samples were collected and analyzed for manmade pollutants and naturally occurring constituents. The samples were collected from six irrigation wells, seven domestic wells, two springs, one stock well, one dairy well, and one observation well. Quality assurance samples also were collected and analyzed. The water samples were analyzed for selected radionuclides, inorganic constituents, organic compounds, and bacteria.

None of the samples analyzed for radionuclides, inorganic constituents, or organic compounds exceeded the established maximum contaminant levels for drinking water. Most of the radionuclide and inorganic constituent concentrations exceeded their respective reporting levels. All the samples analyzed for dissolved organic carbon had concentrations that exceeded their reporting level. Concentrations of 1,1,1-trichloroethane exceeded the reporting level in two water samples. Two samples and a quality assurance replicate contained reportable concentrations of 2, 4-D. One sample contained fecal coliform bacteria counts that exceeded established maximum contaminant levels for drinking water.
\end{abstract}

\section{INTRODUCTION}

Recently, the public has expressed much concern about waste disposal practices at the Idaho National Engineering Laboratory (INEL) and the impact these practices might have had on the water quality of the Snake River Plain aquifer. The U.S. Department of Energy requested that the U.S. Geological Survey (USGS) conduct two studies to respond to the public's concern and to gain a greater understanding of the chemical quality of water in the aquifer. The first study described a one-time sampling effort during May 1989 in the eastern part of the A \& B Irrigation District in Minidoka County (Mann and Knobel, 199()). The second study, an ongoing annual sampling effort in the area between the southem houndary of the INEL and 
Hagerman (fig. 1), is heing conducted in cooperation with the Idaho Department of Water Resources. The initial round of sampling for the second study involved analyzing water samples collected from 55 sites during August and September 1989 (Wegner and Camphell, 1991). Water samples from 19 of the initial 55 sites were collected and analyzed during 1990) (Bartholomay and others, 1992). This report summarizes the analyses of water samples collected during August 199! from 18 more of the initial 55 sites.

The INEL includes about $890 \mathrm{mi}^{2}$ of the northeastem part of the eastem Snake River Plain and is about 110 mi northeast of the Hagerman area (fig. 1). Wastewater containing chemical and radiochemical wastes generated at the INEL was discharged mostly to ponds and wells in the past. Since 1983, most aqueous wastes have been discharged to infiltration ponds. Many of the constituents in the wastewater enter the aquifer indirectly following percolation through the unsaturated zone (Pittman and others, 1988).

Chemical and radioactive wastes have migrated from less than 1 to about 9 mi southwest of the disposal areas at the INEL (Pittman and others, 1988). Tritium was detected at concentrations of less than the reporting level $103,4(1) \pm 2(0) \mathrm{pCi} / \mathrm{L}$ in water from three wells along the southern boundary of the INEL hetween 1983 and 1985. Since April 1986, tritium concentrations in water from wells near the southern boundary of the INEL have been less than the Radiological and Environmental Sciences Laboratory (RESL) analytical method detection limit of $5(\%) \mathrm{pCi} / \mathrm{L}$ (Mann and Cecil, 1990).

Water samples from 18 sites (fig. 2) were analyzed for selected radionuclides, trace elements, common ions, purgeable organic compounds, carbamate and organophosphorus insecticides, organochlorine insecticides, gross polychlorinated biphenyls (PCB's), gross polychlorinated naphthalenes (PCN's), triazine and chlorophenoxy-acid herhicides, surfactants, DOC (dissolved organic carbon), cyanide, and fecal coliform bacteria. In addition, one site sampled in 1996) was resampled for analysis of selected radionuclides by the USGS National Water Quality Laboratory (NWQL) at Arvada, Colo. The same site also was sampled for analysis of selected radionuclides and inorganic constituents by the Idaho State University (ISU) Environmental Monitoring Laboratory at Pocatello, Idaho, and the Idaho Department of Health and Welfare Laboratory (IDHWL) at Twin Falls and Boise, Idaho. Two replicate water samples and one equipment blank also were collected and analyzed as a measure of quality assurance.

\section{Geohydrologic Setting}

The eastern Snake River Plain is a northeast-trending structural basin about 2(1) $\mathrm{mi}$ long and 50) to $70 \mathrm{mi}$ wide. The basin, bounded by faults on the northwest and downwarping and faulting on the southeast, has been filled with basaltic lava flows interhedded with terrestrial sediments (Whitehead, 1986). Individual basalt flows average $201025 \mathrm{ft}$ in thickness with an aggregate thickness of several thousand feet in places. Alluvial fan deposits are composed primarily of sand and gravel, whereas in areas where streams were dammed hy basalt flows, the sediments are predominantly silt and clay (Garabedian, 1986). Rhyolitic lava flows and tuffs are exposed locally at the surface and may exist at depth under most of the castern plain. A 10,365-fi-deep test hole at the INEL penetrated about 2,160 ft of basalt and sediment and 8,205 ft of tuffaceous and rhyolitic volcanic rocks (Mann, 1986).

Movement of water in the aquifer generally is from the northeast to the southwest. Water moves horizontally through hasalt interflow zones and vertically through joints and interfingering edges of the interflow zones. Infiltration of surface water, heavy pumpage, geologic conditions, and seasonal fluxes in recharge and discharge locally affect the movement of ground water (Garabedian, 1986).

The Snake River Plain aquifer is recharged by seepage from the upper reaches of the Snake River, tributaries and canals, infiltration from irrigation and precipitation, and underflow from tributary valleys on the perimeter of the plain. Discharge from the aquifer primarily is by pumpage for irrigation and spring flow (1) the Snake River (Mann and Knobel, 199()). Between 19()2 and 1980), spring flow to the Snake River 


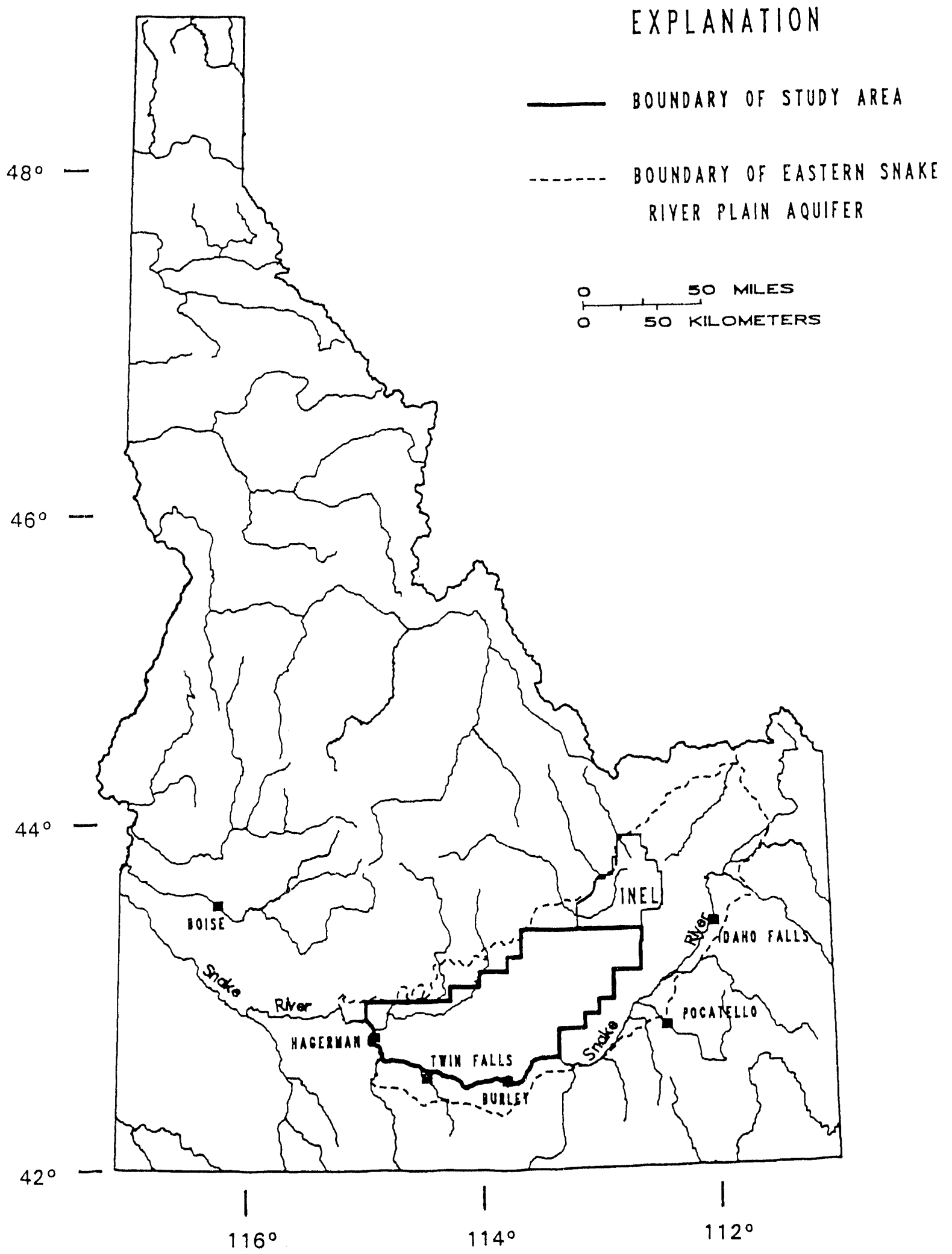

Figure 1.-Location of the study area between the Idaho National Engineering Laboratory and Hagerman, Idaho. 


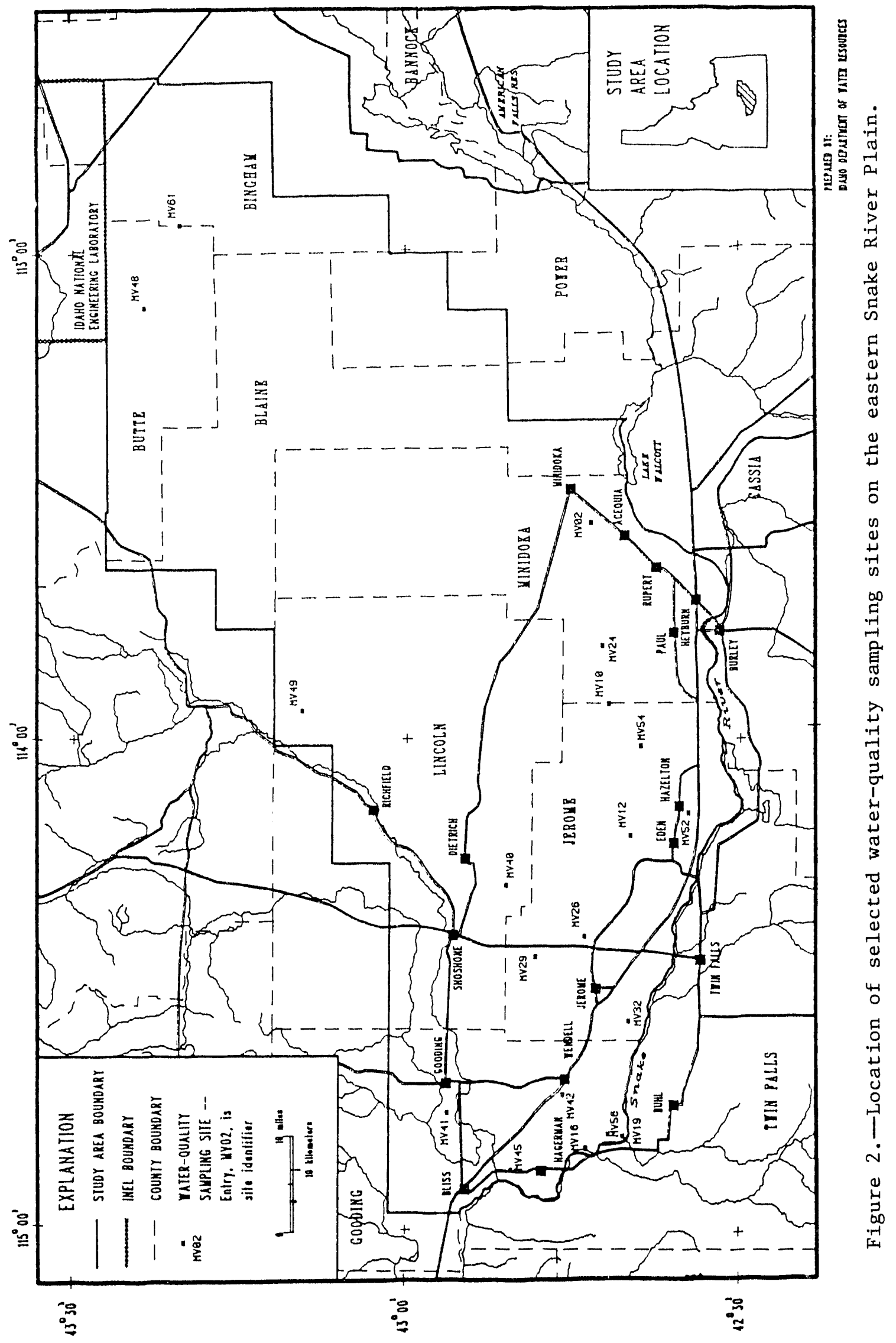


increased about 1.2 million acre-ft/yr, largely as a result of increased recharge from infiltration of irrigation water (Mann, 1989, p. 5).

\section{Acknowledgments}

The authors gratefully acknowledge the well owners for granting permission to collect the water samples and extend special thanks (o) Downy Strode of the Tikura Cattlemen's Association for his help in locating and pumping one of the wells for sample collection. Thanks are extended to the Idaho Image Analysis Facility, located at the ldaho Department of Water Resources, for assistance in preparing maps in this report. The authors are grateful for technical review of the manuscript by Robert Bobo of the Idaho Department of Health and Welfare, and Linda C. Davis of the USGS.

\section{METHODS AND QUALITY ASSURANCE}

The methodology used in sampling for selected chemicals generally followed the guidelines established hy the USGS (Goerlitz and Brown, 1972; Stevens and others, 1975; Wood, 1981; Claassen, 1982; W.L. Bradford, USGS, written commun., 1985; Wershaw and others, 1987; and Fishman and Friedman, 1989). The methods used in the field and guality assurance practices are outlined in following sections.

\section{Site Selection}

Water samples were collected at 18 locations (fig. 2), including 6 irrigation wells, 7 domestic wells, 2 springs, I stock well, I dairy well, and 1 observation well. In addition, one observation well (MV-61) sampled in 1990) was resampled. Two replicate water samples and one equipment blank also were collected. The irrigation wells were equipped with turbine pumps. The domestic, stock, dairy, and observation wells were equipped with submersible pumps. Criteria for site selection were geographic location, case of sample collection, and long-term access.

\section{Sample Containers and Preservatives}

Sample containers and preservatives difier depending on the constituent(s) for which analyses are requested. Samples analyzed by NWQL were collected and preserved in accordance with laboratory requirements specified by Pritt and Jones (1989). Water samples analyzed by ISU were collected in accordance with laboratory requirements specified hy the director of the Environmental Monitoring Program at ISU. Water samples analyzed by IDHW! were collected in accordance with laboratory requirements specified hy the director of the Bureau of Laboratories at IDHWL. Containers and preservatives were supplied by the respective laboratories. Containers and preservatives used for this study are listed on table 1.

\section{Sample Collection}

Irrigation wells were sampled from spigots in discharge lines near pumps; domestic, stock, and dairy wells were sampled from the closest available spigots to pumps; and observation wells were sampled at the well head. All the wells either were pumping on arrival of the sampling team or were started on arrival and, when possible, pumped long enough to ensure that pressure tanks and pumping systems had been thoroughly flushed as evidenced by stable $\mathrm{pH}$, specific conductance, and temperature measurements. The two springs were sampled as near the source as possible by collecting a grab sample from an area of moving water. 
Table 1.-Containers and preservatives used for water-sample collection

IAbbreviations: gal, gallon; g, graın; L, liter; $\mathrm{mL}$, milliliter; $\mu \mathrm{m}$, micrometer; ${ }^{\circ} \mathrm{C}$, degrees Celsius; $\mathrm{HgCl}_{2}$, mercuric chloride; $\mathrm{NaCl}$, sodium chloride; $\mathrm{HNO}_{3}$, nitric acid; $\mathrm{K}_{2} \mathrm{Cr}_{2} \mathrm{O}_{7}$, potassium dichromate; $\mathrm{NaOH}$, sodium hydroxide. Chilled samples were shipped by overnight-delivery mail. Analyzing laboratory: NWQL--U.S. Geological Survey's National Water Quality Laboratory; IDHWLIdaho Department of Health and Welfare Laboratory; ISU-Idaho State University's Environmental Monitoring Laboratory]

\begin{tabular}{|c|c|c|c|c|c|c|}
\hline \multirow{2}{*}{$\begin{array}{l}\text { Type of } \\
\text { constituent }\end{array}$} & \multicolumn{2}{|c|}{ Container } & \multicolumn{2}{|l|}{ Preservative } & \multirow{2}{*}{$\begin{array}{l}\text { Other } \\
\text { treatment }\end{array}$} & \multirow{2}{*}{$\begin{array}{l}\text { Laborato } \\
\text { providin } \\
\text { analyses }\end{array}$} \\
\hline & Type & Size & Type & Size & & \\
\hline Pesticides & Glass, baked & $1 \mathrm{~L}$ & None & None & Chill $4^{\circ} \mathrm{C}$ & NWQL \\
\hline Nutrients & $\begin{array}{l}\text { Polyethylene, } \\
\text { brown }\end{array}$ & $250 \mathrm{~mL}$ & $\begin{array}{l}\mathrm{HgCl}_{2} / \\
\mathrm{NaCl}\end{array}$ & $1 \mathrm{~mL}$ & $\begin{array}{l}0.45 \mu \mathrm{m} \\
\text { filter, } \\
\text { chill } 4^{\circ} \mathrm{C}\end{array}$ & NWQL \\
\hline \multicolumn{7}{|c|}{ Purgeable organic } \\
\hline & Glass, baked & $40 \mathrm{~mL}$ & Ascorbic acid & $0.05 \mathrm{~g}$ & Chill $4^{\circ} \mathrm{C}$ & IDHWL \\
\hline \multirow[t]{3}{*}{ Trace elements } & $\begin{array}{l}\text { Polyethylene, } \\
\text { acid-rinsed }\end{array}$ & $500 \mathrm{~mL}$ & $\mathrm{HNO}_{3}$ & $2 \mathrm{~mL}$ & $\begin{array}{l}0.45 \mu \mathrm{m} \\
\text { filter }\end{array}$ & NWQL \\
\hline & $\begin{array}{l}\text { Polyethylene, } \\
\text { acid-rinsed }\end{array}$ & $1 \mathrm{~L}$ & $\mathrm{HNO}_{3}$ & $5 \mathrm{~mL}$ & $\begin{array}{l}0.45 \mu \mathrm{m} \\
\text { filter }\end{array}$ & IDHWL \\
\hline & $\begin{array}{l}\text { Polyethylene, } \\
\text { acid-rinsed }\end{array}$ & $1 \mathrm{~L}$ & $\mathrm{HNO}_{3}$ & $5 \mathrm{~mL}$ & None & IDHWL \\
\hline Mercury & $\begin{array}{l}\text { Glass, } \\
\text { acid-rinsed }\end{array}$ & $250 \mathrm{~mL}$ & $\begin{array}{l}\mathrm{K}_{2} \mathrm{Cr}_{2} \mathrm{O}_{7} / \\
\mathrm{HNO}_{3}\end{array}$ & $10 \mathrm{~mL}$ & $\begin{array}{l}0.45 \mu \mathrm{m} \\
\text { filter }\end{array}$ & NWQL \\
\hline \multirow[t]{2}{*}{ Tritium } & Glass, baked & $1 \mathrm{~L}$ & None & None & None & NWQL \\
\hline & Polyethylene & $500 \mathrm{~mL}$ & None & None & None & ISU \\
\hline Radium & $\begin{array}{l}\text { Polyethylene, } \\
\text { acid-rinsed }\end{array}$ & $1 \mathrm{~L}$ & $\mathrm{HNO}_{3}$ & $4 \mathrm{~mL}$ & $\begin{array}{l}0.45 \mu \mathrm{m} \\
\text { filter }\end{array}$ & NWQL \\
\hline Radon-222 & Glass vials & $20 \mathrm{~mL}$ & $\begin{array}{l}\text { Scintillation } \\
\text { cocktail }\end{array}$ & $10 \mathrm{~mL}$ & None & NWQL \\
\hline
\end{tabular}


Table 1.-Containers and preservatives used for water-sample collection--Continued

\begin{tabular}{|c|c|c|c|c|c|c|}
\hline \multirow{2}{*}{$\begin{array}{l}\text { Type of } \\
\text { constituent }\end{array}$} & \multicolumn{2}{|c|}{ Container } & \multicolumn{2}{|c|}{ Preservative } & \multirow{2}{*}{$\begin{array}{l}\text { Other } \\
\text { treatment }\end{array}$} & \multirow{2}{*}{$\begin{array}{l}\text { Laboratory } \\
\text { providing } \\
\text { analyses }\end{array}$} \\
\hline & Type & Size & Type & Size & & \\
\hline \multirow[t]{2}{*}{ Strontium-90 } & $\begin{array}{l}\text { Polyethylene, } \\
\text { acid-rinsed }\end{array}$ & $1 \mathrm{~L}$ & $\mathrm{HNO}_{3}$ & $4 \mathrm{~mL}$ & $\begin{array}{l}0.45 \mu \mathrm{m} \\
\text { filter }\end{array}$ & NWQL \\
\hline & Polyethylene & $1 \mathrm{gal}$ & None & None & None & ISU \\
\hline Uranium & $\begin{array}{l}\text { Polyethylene, } \\
\text { acid-rinsed }\end{array}$ & $1 \mathrm{~L}$ & $\mathrm{HNO}_{3}$ & $4 \mathrm{~mL}$ & $\begin{array}{l}0.45 \mu \mathrm{m} \\
\text { filter }\end{array}$ & NWQL \\
\hline \multirow[t]{2}{*}{$\begin{array}{l}\text { Other radio- } \\
\text { nuclides }\end{array}$} & $\begin{array}{l}\text { Polyethylene, } \\
\text { acid-rinsed }\end{array}$ & $1 \mathrm{~L}$ & None & None & None & NWQL \\
\hline & Polyethylene & 1 gai & None & None & None & ISU \\
\hline Bacteria & $\begin{array}{l}\text { Polyethylene, } \\
\text { autoclaved }\end{array}$ & $250 \mathrm{~mL}$ & None & None & Chill $4^{\circ} \mathrm{C}$ & IDHWL \\
\hline $\begin{array}{l}\text { Dissolved } \\
\text { organic } \\
\text { carbon }\end{array}$ & Glass, baked & $125 \mathrm{~mL}$ & None & None & $\begin{array}{l}\text { Silver } \\
\text { filter, } \\
\text { chill } 4^{\circ} \mathrm{C}\end{array}$ & NWQL \\
\hline Surfactants & Polyethylene & $250 \mathrm{~mL}$ & None & None & Chill $4^{\circ} \mathrm{C}$ & NWQL \\
\hline Cyanide & Polyethylene & $250 \mathrm{~mL}$ & $\mathrm{NaOH}$ & $5 \mathrm{~mL}$ & Chill $4^{\circ} \mathrm{C}$ & NWQL \\
\hline \multirow[t]{5}{*}{ Common ions } & $\begin{array}{l}\text { Polyethylene, } \\
\text { acid-rinsed }\end{array}$ & $500 \mathrm{~mL}$ & $\mathrm{HNO}_{3}$ & $2 \mathrm{~mL}$ & $\begin{array}{l}0.45 \mu \mathrm{m} \\
\text { filter }\end{array}$ & NWQL \\
\hline & $\begin{array}{l}\text { Polyethylene, } \\
\text { acid-rinsed }\end{array}$ & $500 \mathrm{~mL}$ & $\mathrm{HNO}_{3}$ & $2 \mathrm{~mL}$ & None & NWQL \\
\hline & Polyethylene & $250 \mathrm{~mL}$ & None & None & $\begin{array}{l}0.45 \mu \mathrm{m} \\
\text { filter }\end{array}$ & NWQL \\
\hline & Polyethylene & $250 \mathrm{~mL}$ & None & None & None & NWQL \\
\hline & $\begin{array}{l}\text { Polyethylene, } \\
\text { acid-rinsed }\end{array}$ & $1 \mathrm{~L}$ & None & None & Chill $4^{\circ} \mathrm{C}$ & IDHWL \\
\hline
\end{tabular}


Chemical and physical characteristics monitored at the water-sampling sites included $\mathrm{pH}$, specific conductance, temperature, alkalinity, and concentrations of dissolved oxygen. These characteristics were monitored during pumping using methods described by Wood (1981) and Hardy and others (1989). A water sample was collected when measurements of these properties indicated probable hydraulic and chemical stability. After collection, sample containers were sealed with laboratory film, labeled, and packed into ice chests for shipment by overnight-delivery mail to the NWQL. The samples collected for the IDHWL and ISU were stored in coolers until they were hand-delivered to the respective laboratories.

Measurements of $\mathrm{pH}$, specific conductance, water temperature, alkalinity, and concentrations of dissolved oxygen are shown on table 2. Measured $\mathrm{pH}$ of water from sampling sites ranged from 7.5 to 8.1 , which is within the U.S. Environmental Protection Agency's (1989) recommended range of 6.5 to 8.5 for community water systems. Specific conductance measurements ranged from 340 to $1,080 \mu \mathrm{S} / \mathrm{cm}$. Measurements of temperature ranged from 11.5 to $16.5^{\circ} \mathrm{C}$. The Idaho Department of Health and Welfare (IDHW, 1989) has established a secondary maximum contaminant level of $26.6^{\circ} \mathrm{C}$ for temperature. All the temperature measurements were below this level. Alkalinity as calcium carbonate ranged from 126 to $286 \mathrm{mg} / \mathrm{L}$. Concentrations of dissolved oxygen ranged from 6.8 to $9.8 \mathrm{mg} / \mathrm{L}$.

Conditions at the sampling site during sample collection were recorded in a field logbook; a chain-ofcustody record was used to track the samples from the time of collection until delivery to the analyzing laboratory. These records are available for inspection at the USGS Project Office at the INEL.

\section{Quality Assurance}

Detailed descriptions of intemal quality control and overall quality assurance practices used by the NWQL are provided in reports by Friedman and Erdmann (1982) and Jones (1987). Water samples analyzed by NWQL were collected in accordance with a quality assurance plan for quality of water activities conducted by personnel assigned to the INEL Project Office; the plan was finalized in June 1989, and is available for inspection at the USGS Project Office at tie INEL. Water samples analyzed by IDHWL were collected in accordance with procedures described by W. Baker, J. Dodds, and B. Ellis (IDHW, written communs., 1991). Water samples analyzed by ISU were collected in accordance with procedures described by B. Graham (ISU, written commun., 1991). Ten percent of the water samples were quality assurance samples. Sample MV-28 is a replicate of sample MV-24. Sample MV-34 is a replicate of sample MV-40. Sample MV-61 is a resample for selected radionuclides. Sample MV-62 is an equipment blank analyzed for purgeable organic compounds and selected dissolved trace elements. Sample MV- 62 contained $0.22 \mu \mathrm{g} / \mathrm{L}$ of chloroform. Because none of the other samples contained reportable concentrations of chloroform, the blank water may have been contaminated.

\section{RADIONUCLIDES}

Water samples were analyzed for radon-222, strontium-90, tritium, gross alpha- and gross beta-particle radioactivity, total uranium, radium-226, and radium-228. In addition, gamma-emitting radionuclides were identified. The samples were analyzed using methods described by Thatcher and others (1977) and U.S. Environmental Protection Agency (1987). Maximum contaminant levels for the types of radioactivity and for selected radionuclides are listed on table 3.

An analytical uncertainty, $\mathbf{s}$, is calculated for each radionuclide concentration. This report presents the analytical uncertainty as $2 \mathbf{s}$. Guidelines for interpreting analytical results are based on an extension of the method described by Currie (1984). In radiochemical analyses, laboratory measurements are made on a target sample and a prepared blank. Instrument signals for the sample and blank vary randomly. Therefore, it is 
Table 2.-Results of field measurements of water for $\mathrm{pH}$, specific conductance, temperature, alkalinity, and concentrations of dissolved oxygen from selected wells and springs, eastern Snake River Plain

|Site identifier: see figure 2 for location of sites. Site use: H--domestic; I--irrigation; D--dairy; Sp--spring; QA--quality assurance (see Quality Assurance section in text for explanation); O--observation; S--stock. Date sampled: month/day/year. pH: negative base-10 logarithm of hydrogen ion activity, in moles per liter. Specific conductance: microsiemens per centimeter at $25^{\circ} \mathrm{C}$ (degrees Celsius). Temperature: ${ }^{\circ} \mathrm{C}$. Alkalinity: $\mathrm{mg} / \mathrm{L}$ as calcium carbonate. Dissolved oxygen: $\mathrm{mg} / \mathrm{L}$ using Azide modification of Winkler method (American Public Health Association and Water Pollution Control Federation, 1985). -- indicates no analysis was performed]

\begin{tabular}{|c|c|c|c|c|c|c|c|}
\hline $\begin{array}{c}\text { Site } \\
\text { identifier }\end{array}$ & $\begin{array}{l}\text { Site } \\
\text { use }\end{array}$ & $\begin{array}{c}\text { Date } \\
\text { sampled }\end{array}$ & $\mathrm{pH}$ & $\begin{array}{c}\text { Specific } \\
\text { conductance }\end{array}$ & $\begin{array}{l}\text { Temper- } \\
\text { ature }\end{array}$ & $\begin{array}{l}\text { Alka- } \\
\text { linity }\end{array}$ & $\begin{array}{c}\text { Dissolved } \\
\text { oxygen }\end{array}$ \\
\hline MV-(02 & $\mathrm{H}$ & $(08 / 12 / 91$ & 7.9 & 580 & 14.5 & 171 & 6.8 \\
\hline MV-10 & 1 & $(08 / 12 / 91$ & 7.8 & 800 & 14.0 & 200 & 8.1 \\
\hline MV-12 & $\mathrm{D}$ & $08 / 14 / 91$ & 7.9 & 715 & 15.0 & 181 & 9.0 \\
\hline MV-16 & $\mathrm{Sp}$ & $08 / 13 / 91$ & 7.9 & 410 & 15.0 & 148 & 8.6 \\
\hline MV-19 & $\mathrm{Sp}$ & $(08 / 15 / 91$ & 8.0 & 498 & 15.0 & 157 & 9.0 \\
\hline MV-24 & $\mathrm{H}$ & $08 / 12 / 91$ & 7.7 & $1,(180)$ & 15.0 & 271 & 7.6 \\
\hline MV-26 & I & $08 / 16 / 91$ & 8.0 & 466 & 14.0 & 142 & 9.1 \\
\hline MV-28 & QA & $08 / 12 / 91$ & 7.7 & 1,080 & 15.0 & 271 & 7.6 \\
\hline MV-29 & I & $08 / 14 / 91$ & 8.1 & 345 & 14.5 & 126 & 8.8 \\
\hline MV-32 & $\mathrm{H}$ & $08 / 15 / 91$ & 7.8 & 720 & 15.5 & 230 & 7.9 \\
\hline MV-34 & $\mathrm{QA}$ & $08 / 15 / 91$ & 8.0 & 340 & 14.5 & 136 & 8.2 \\
\hline $\mathrm{MV}-40$ & I & $08 / 15 / 91$ & 8.0 & 340 & 14.5 & 136 & 8.2 \\
\hline MV-41 & $I$ & $08 / 13 / 91$ & 7.5 & 780 & 14.5 & 286 & 7.9 \\
\hline$M V-42$ & $\mathrm{H}$ & $08 / 13 / 91$ & 7.8 & 465 & 16.5 & 175 & 8.3 \\
\hline MV-45 & I & $08 / 13 / 91$ & 8.0 & 380 & 16.0 & 154 & 8.2 \\
\hline MV-48 & $\mathrm{O}$ & $08 / 21 / 91$ & 8.1 & 365 & 13.0 & 146 & 8.0 \\
\hline MV-49 & $\mathrm{S}$ & $08 / 21 / 91$ & 7.6 & 388 & 11.5 & 185 & 9.8 \\
\hline MV-52 & $\mathrm{H}$ & $(08 / 14 / 91$ & 7.8 & 630 & 16.5 & 220 & 8.7 \\
\hline MV-54 & $\mathrm{H}$ & $08 / 14 / 91$ & 7.8 & 842 & 15.0 & 226 & 9.0 \\
\hline MV-56 & $\mathrm{H}$ & $08 / 16 / 91$ & 7.9 & 414 & 15.0 & 140 & 8.3 \\
\hline MV-61 & $\mathrm{O}$ & $08 / 21 / 91$ & 8.1 & 384 & 15.5 & -- & - \\
\hline
\end{tabular}


Table 3.-Maximum contaminant levels for types of radioactivity and selected radionuclides in drinking water

IThe maximum contaminant levels were established pursuant to the recommendations of the U.S. Environmental Protection Agency (1989, p. 55()) for community water systems and are for comparison purposes only. The proposed maximum contaminant level - in parentheses-are from U.S. Environmental Protection Agency (1991). The maximum contaminant level given for gross alpha-particle radioactivity includes radium-226 but excludes radon and uranium. The maximum contaminant level given for gross beta-particle radioactivity excludes radioactivity from natural sources and is included for comparison purposes only. Maximum contaminant level values listed for strontium-9() and tritium are average annual concentrations assumed to produce a total body or organ dose of $4 \mathrm{mrem} / \mathrm{yr}$ (millirem per year) of beta-particle radiation. Abbreviations: pCi/L--picocurie per liter, $\mu \mathrm{g} / \mathrm{L}$--microgram per liter]

\section{Type of radioactivity} or radionuclide

Maximum contaminant level

Gross alpha-particle radioactivity

Gross beta-particle and gamma radioactivity

Radium-226 plus radium-228

Radium-226

Radium-228

Radon-222

Strontium-90

Total uranium

Tritium
$15 \mathrm{pCi} / \mathrm{L}$

$4 \mathrm{mrem} / \mathrm{yr}$

$5 \mathrm{pCi} / \mathrm{L}$

$(20 \mathrm{pCi} / \mathrm{L})$

(20) $\mathrm{pCi} / \mathrm{L}$ )

$(300 \mathrm{pCi} / \mathrm{L})$

$8 \mathrm{pCi} / \mathrm{L}$

$(20 \mu \mathrm{g} / \mathrm{L})$

$20,000 \mathrm{pCi} / \mathrm{L}$ 
essential to distinguish between two key aspects of the problem of detection: (1) The instrument signal for the sample must be greater than the signal for the blank to make the decision that there was detection; and (2) an estimation must be made of the minimum concentration that will yield a sufficiently large signal to make the correct decision for detection or nondetection most of the time. The first aspect of the problem is a qualitative decision based on signals and a definite criterion for detection. The second aspect of the problem is an estimation of the detection capabilities of a complete measurement process that includes hypothesis testing.

In the laboratory, instrument signals must exceed a critical level to make the qualitative decision whether the radionuclide or radioactivity was detected. Concentrations that equal $1.6 \mathrm{~s}$ meet this criterion; at $1.6 \mathrm{~s}$, there is about a 95-percent probability that the correct decision-not detected-will be made. Given a large number of samples, as many as 5 percent of the samples with measured concentrations greater than or equal to 1.6s, which were concluded as being detected, might not contain the radioactive constituent. These measurements are referred to as false positives and are errors of the first kind in hypothesis testing.

Once the critical level of $1.6 \mathrm{~s}$ has been defined, the minimum detectable concentration can be established. Concentrations that equal $3 \mathrm{~s}$ represent a measurement at the minimum detectable concentration. For true concentrations of $3 \mathbf{s}$ or greater, there is a 95 -percent-or-more probability of correctly concluding that the radioactive constituent was detected in a sample. Given a large number of samples, as many as 5 percent of the samples with measured concentrations greater than or equal to $3 \mathrm{~s}$, which were concluded as being not detected, could contain the radioactive constituent at the minimum detectable concentration. These measurements are referred to as false negatives and are errors of the second kind in hypothesis testing.

True radionuclide concentrations between $1.6 \mathrm{~s}$ and $3 \mathrm{~s}$ have larger errors of the second kind. That is, there is a greater-than-5-percent probability of false negative results for samples with true concentrations between $1.6 \mathrm{~s}$ and $3 \mathrm{~s}$, and although the radionuclide or radioactivity might have been detected, such detection may not be considered reliable; at $1.6 \mathrm{~s}$, the probability of a false negative is about 50 percent.

These guidelines are based on counting statistics alone and do not include systematic or random errors inherent in laboratory procedures. The values $1.6 \mathrm{~s}$ and $3 \mathrm{~s}$ vary slightly with background or blank counts and with the number of gross counts for individual analyses. The use of the critical level and minimum detectable concentration aids the reader in the interpretation of analytical results and does not represent absolute concentrations of radioactivity that may or may not have been detected. In this report, if the concentration of a selected radionuclide was equal to or greater than $3 \mathrm{~s}$, the concentration is considered to be above a "reporting level." The reporting level should not be confused with the analytical method detection limit, which is hased on laboratory procedures. At small concentrations, the reporting level approaches the analytical method detection limit; however, at larger concentrations, they may he significantly different.

\section{Radon-222}

Radon-222 is a naturally occurring radioactive gas that results from the decay of radium-226. Concentrations of radon-222 in 10 water samples analyzed by NWQL exceeded the reporting level and ranged from $66 \pm 29$ to $152 \pm 34 \mathrm{pCi} / \mathrm{L}$ (table 4). Concentrations in all the samples were below the proposed maximum contaminant level of $300 \mathrm{pCi} / \mathrm{L}$ (table 3).

\section{Strontium-90}

Strontium-9() is a fission product that was widely distributed in the environment during atmospheric weapons tests. Strontium-90 generally is present in ground water as a result of these tests and from nuclear industry waste-disposal practices. All water samples analyzed by NWQL contained dissolved strontium-90) 
Table 4.-Concentrations of radon-222, strontium-90, and tritium in water from selected wells and springs, eastern Snake River Plain

IAnalyses were performed by the U.S. Geological Survey's National Water Quality Laboratory (NWQL) and Idaho State University's (ISU) Environmental Monitoring Laboratory using the following methods: radon-222 by liquid scintillation; tritium by enrichment and gas counting at NWQL and by liquid scintillation at ISU; strontium-9() by chemical separation and precipitation. Analytical results and uncertainties---for example, $79 \pm 46$ - in $\mathrm{pCi} / \mathrm{L}$ (picocurie per liter). Analytical uncertainties are reported as $2 \mathrm{~s}$. Site identifier: see figure 2 for location of sites. Symbols: * indicates quality assurance sample (MV-28 is a replicate of MV-24; MV-34 is a replicate of MV-40); -- indicates no analysis was performed]

\begin{tabular}{|c|c|c|c|c|c|}
\hline $\begin{array}{c}\text { Site } \\
\text { identifier }\end{array}$ & $\begin{array}{l}\text { Radon-222 } \\
\text { NWQL }\end{array}$ & $\begin{array}{l}\text { Strontium-9() } \\
\text { NWQL }\end{array}$ & $\begin{array}{l}\text { Strontium-90 } \\
\quad \text { ISU }\end{array}$ & $\begin{array}{l}\text { Tritium } \\
\text { NWQL }\end{array}$ & $\begin{array}{l}\text { Tritium } \\
\text { ISU }\end{array}$ \\
\hline MV-()2 & $79 \pm 46$ & $0.106 \pm 0.217$ & $-3.6 \pm 2.0$ & $37.4 \pm 2.56$ & $150 \pm 220$ \\
\hline MV-10 & $70 \pm 31$ & $.090 \pm 0.192$ & $-3.4 \pm 1.0$ & $48.3 \pm 3.20$ & $150 \pm 220$ \\
\hline$M V-12$ & $42 \pm 47$ & $.007 \pm 0.190$ & $0 \pm 0.6$ & $39.7 \pm 2.56$ & $70 \pm 200$ \\
\hline MV-16 & $106 \pm 34$ & $.093 \pm 0.220$ & $-.8 \pm(1.4$ & $13.6 \pm(1.90$ & $60 \pm 200$ \\
\hline MV-19 & $45 \pm 36$ & $.040 \pm 0.207$ & $-3.3 \pm 1.0$ & $15.4 \pm 0.77$ & $40 \pm 200$ \\
\hline MV-24 & $43 \pm 31$ & $.055 \pm 0.195$ & $(0 \pm 0.2$ & $82.6 \pm 5.76$ & $230 \pm 220$ \\
\hline MV-26 & $15 \pm 34$ & $.024 \pm(0.200$ & $-4.0 \pm 1.2$ & $9.5 \pm(1) .77$ & $10 \pm 200$ \\
\hline MV $-28^{*}$ & $81 \pm 32$ & $.210 \pm 0.233$ & $-2.7 \pm 1.0$ & $90.6 \pm 5.76$ & $90 \pm 220$ \\
\hline MV-29 & $107 \pm 41$ & $.091 \pm 0.214$ & $-.3 \pm(1) .6$ & $3.81 \pm(1.58$ & $180 \pm 220$ \\
\hline MV-32 & $15 \pm 41$ & $.120 \pm 0.223$ & $.8 \pm 0.6$ & $73.6 \pm 5.12$ & $240 \pm 220$ \\
\hline MV-34* & $137 \pm 37$ & $.060 \pm 0.238$ & -- & $14.2 \pm 0.96$ & -- \\
\hline MV-40 & $56 \pm 42$ & $.022 \pm 0.196$ & $-.4 \pm 0.6$ & $13.7 \pm 10.90$ & $80 \pm 200$ \\
\hline MV-41 & $26 \pm 26$ & $.062 \pm 0.213$ & $.5 \pm 1.0$ & $70.4 \pm 4.48$ & $200 \pm 220$ \\
\hline MV -42 & $152 \pm 34$ & $.188 \pm 0.222$ & $0 \pm 0.8$ & $29.8 \pm 1.98$ & $120 \pm 200$ \\
\hline MV-45 & $124 \pm 26$ & $.104 \pm 0.200$ & $-.3 \pm 0.6$ & $22.6 \pm 1.47$ & $100 \pm 220$ \\
\hline MV-48 & $138 \pm 61$ & $.120 \pm 0.363$ & $.1 \pm(1) .6$ & $29.2 \pm 1.92$ & $250 \pm 220$ \\
\hline MV-49 & $82 \pm 62$ & $-.085 \pm 0.199$ & $-4.3 \pm 1.4$ & $85.4 \pm 5.76$ & $240 \pm 220$ \\
\hline MV-52 & $66 \pm 29$ & $.052 \pm 0.216$ & $-.4 \pm 0.6$ & $78.1 \pm 5.12$ & $220 \pm 220$ \\
\hline MV-54 & $43 \pm 31$ & $.155 \pm 0.238$ & $-.6 \pm 1) .8$ & $85.4 \pm 5.76$ & $40 \pm 200$ \\
\hline MV-56 & $31 \pm 35$ & $.162 \pm 0.225$ & $1.0 \pm(1) .8$ & $9.76 \pm 0.64$ & $140 \pm 220$ \\
\hline MV-61 & -. & $.076 \pm 0.133$ & $-2.3 \pm(1) .8$ & -- & $140 \pm 220$ \\
\hline
\end{tabular}


concentrations less than the reporting level (table 4). All the samples analyzed by ISU contained total strontium-90 concentrations less than the reporting level.

In 1989, MV-61 had a strontium-90 concentration $(2.93 \pm 0.40 \mathrm{pCi} / \mathrm{L})$ greater than the reporting level, whereas a quality assurance replicate sample (MV-60) had a concentration (0.06 $(0) .18 \mathrm{pCi} / \mathrm{L}$ ) less than the reporting level (Wegner and Camphell, 1991). To clarify these results, MV-61 was sampled in 1990) (Bartholomay and others, 1992) and was resampled in 1991. Both of these later samples contained strontium-90 concentrations less than the reporting level.

\section{Tritium}

Tritium, a radioactive isotope of hydrogen, is formed in nature by interactions of cosmic rays with gases in the upper atmosphere. Tritium also is produced in thermonuclear detonations and is a waste product of the nuclear power industry. Samples were submitted to the NWQL and the ISU laboratory. The NWQL used an enrichment and gas-counting technique and the ISU laboratory used a liquid scintillation technique. The analytical method detection limit for the laboratories differed. The analytical method detection limit for the ISU laboratory was $300 \mathrm{pCi} / \mathrm{L}$ using a 20() -minute counting period, and that for the $\mathrm{NWQL}$ was $0.3 \mathrm{pCi} / \mathrm{L}$ using a 360-10 1,20()-minute counting period.

The concentrations of tritium in the water samples are shown on table 4. All the water samples analyzed by NWQL cortlained concentrations of tritium larger than the reporting level; concentrations ranged from $3.81 \pm(0.581090 .6 \pm 5.76 \mathrm{pCi} / \mathrm{L}$. Tritium concentrations in all water semples analyzed by the ISU laboratory were helow the reporting level. For the purpose of comparison, hackground concentrations of tritium in ground water in ldaho generally range from $75 \mathrm{to} 150 \mathrm{pCi} / \mathrm{L}$ (Orr and others, 1991). The maxirnum contaminant level for tritium in public drinking-water supplies is $20,0(0) \mathrm{pCi} / \mathrm{L}$ (table 3 ).

\section{Gross Alpha-Particle Radioactivity}

Gross alpha-particle radioactivity is a measure of the total radioactivity given off as alpha particles during the radioactive decay process; however, laboratories nomally report the radioactivity as if it were all given off hy one radionuclide. In this report, concentrations are reported both as natural uranium in micrograms per liter and as thorium-230) in picocuries per liter by the NWQL, and as americium-241 in picocuries per liter by the ISU lahoratory.

The gross alpha-particle radioactivity in the dissolved fraction of all the water samples analyzed by NWQL exceeded the reporting level (table 5). The concentrations reported as uranium ranged from $1.7(40.840107 .65 \pm 1.69 \mu \mathrm{g} / \mathrm{L}$. The concentrations reported as thorium-2.30 ranged from $1.19 \pm 0.588 \mathrm{to}$ $5.24 \pm 1.15 \mathrm{pCi} / \mathrm{L}$. Gross alpha-particle radioactivity in the suspended fraction of all the water samples analyzed by NWQL were less than the reporting level. Gross alpha-particle radioactivity reported as total americium-241 in all the water samples analyzed hy ISU were less than the reporting level. Total concentrations of dissolved and suspended fractions of gross alpha-particle radioactivity in all the water samples were less than the maximum contaminant level of $15 \mathrm{pCi} / \mathrm{L}$ (table 3 ).

\section{Gross Beta-Particle Radioactivity}

Gross heta-particle radioactivity is a measure of the total radioactivity given off as beta particles during the radioactive decay process. Laboratory instruments for these measurements are calibrated to a single radionuclide, cesium-137, or a chemically similar pair of radionuclides in equilibrium, strontium-90) in equilibrium with yttrium-9(). In this report, concentrations are reported as strontium-90) in equilibrium with 
Table 5.-Concentrations of gross alpha-particle radioactivity in water from selected wells and springs, eastern Snake River Plain

Analyses were performed by the U.S. Geological Survey's National Water Quality Laboratory (NWQL) and the Idaho State University's (ISU) Environmental Monitoring Laboratory using a residue procedure. Analytical results and uncertainties for example, 1.7() $\pm(0.84($ - - in indicated units. Analytical uncertainties are reported as 2 s. Site identifier: see figure 2 for location of sites.

Abbreviations: $\mu \mathrm{g} / \mathrm{L}-$-microgram per liter; $\mathrm{pCi} / \mathrm{L}$--picocurie per liter. Symbols: * indicates quality assurance sample (MV-28 is a replicate of MV-24; MV-34 is a replicate of MV-40)). -- indicates no analysis was performedl

\begin{tabular}{|c|c|c|c|c|c|}
\hline $\begin{array}{c}\text { Site } \\
\text { identifier }\end{array}$ & $\begin{array}{l}\text { Dissolved as } \\
\text { uranium } \\
\text { NWQL } \\
(\mu \mathrm{g} / \mathrm{L})\end{array}$ & $\begin{array}{l}\text { Dissolved as } \\
\text { thorium-230) } \\
\text { NWQL } \\
(\mathrm{pCi} / \mathrm{L})\end{array}$ & $\begin{array}{l}\text { Suspended as } \\
\text { uranium } \\
\text { NWQL } \\
(\mu \mathrm{g} / \mathrm{L})\end{array}$ & $\begin{array}{l}\text { Suspended as } \\
\text { thorium-230 } \\
\text { NWQL } \\
(\mathrm{pCi} / \mathrm{L})\end{array}$ & $\begin{array}{l}\text { Total as } \\
\text { americium-241 } \\
\text { ISU } \\
(\mathrm{pCi} / \mathrm{L})\end{array}$ \\
\hline MV-(1)2 & $1.70 \pm 0.840$ & $1.19 \pm 0.588$ & $-(0.241 \pm() .308$ & $-(0.162 \pm 0.180$ & $-1.5 \pm 1.8$ \\
\hline$M V-10$ & $4.84 \pm 1.38$ & $3.35 \pm 0.970$ & $-.198 \pm(0.362$ & $-.105 \pm(0.197$ & $.1 \pm 2.8$ \\
\hline$M V-12$ & $3.29 \pm 1.13$ & $2.28 \pm 0.790$ & $-.0(09 \pm 0.440$ & $-.005 \pm 0.247$ & $.1 \pm 2.8$ \\
\hline MV-16 & $2.82 \pm 1.04$ & $1.95 \pm 0.727$ &.$-(125 \pm 0.269$ & $-.017 \pm 0.184$ & $-1.1 \pm 1.4$ \\
\hline MV-19 & $3.39 \pm 1.12$ & $2.36 \pm 0.776$ &.$-(009 \pm 0.444$ & $-.0(05 \pm(1) .250$ & $-1.4 \pm 1.4$ \\
\hline MV-24 & $4.86 \pm 1.38$ & $3.53 \pm 1.00$ & $-.121 \pm 0.235$ & $-.066 \pm 0.130$ & $-2.4 \pm 3.0$ \\
\hline MV-26 & $2.23 \pm 0.914$ & $1.59 \pm 0.654$ & $-.109 \pm 0.155$ & $-.063 \pm 0.093$ & $-1.7 \pm 1.4$ \\
\hline MV-28* & $5.28 \pm 1.46$ & $3.69 \pm 1.03$ & $-.120 \pm() .232$ & $-.063 \pm 0.124$ & $-4.2 \pm 3.2$ \\
\hline MV-29 & $2.15 \pm 0.913$ & $1.55 \pm 0.660$ & $.356 \pm 0.608$ & $.2(07 \pm 0.356$ & $-.2 \pm 1.6$ \\
\hline MV-32 & $5.30 \pm 1.47$ & $3.75 \pm 1.05$ & $.358 \pm 0.455$ & $.268 \pm 0.344$ & $.1 \pm 2.8$ \\
\hline MV-34* & $2.38 \pm 0.982$ & $1.66 \pm 0.689$ & $-.117 \pm 0.228$ & $-.065 \pm 0.128$ & -- \\
\hline$M V-40$ & $2.34 \pm 0.987$ & $1.63 \pm 0.691$ & $-.230 \pm 0.281$ & $-.13(0 \pm 0.166$ & $1.4 \pm 1.8$ \\
\hline$M V-41$ & $7.65 \pm 1.69$ & $5.24 \pm 1.15$ & $.082 \pm 0.472$ & $.048 \pm 0.273$ & $-.7 \pm 2.6$ \\
\hline$M V-42$ & $4.58 \pm 1.32$ & $3.18 \pm 0.928$ & $.029 \pm 0.514$ & $.015 \pm 0.272$ & $1.8 \pm 1.4$ \\
\hline$M V-45$ & $1.87 \pm 0.797$ & $1.27 \pm 0.541$ & $-.057 \pm 0.435$ &.$-(03() \pm() .232$ & $-1.1 \pm 1.2$ \\
\hline$M V-48$ & $2.79 \pm 1.03$ & $1.95 \pm 0.719$ & -.14()$\pm 0.340$ &.$-(076 \pm 0.187$ & $-1.2 \pm 1.2$ \\
\hline MV-49 & $2.27 \pm 0.911$ & $1.56 \pm 0.633$ & $.146 \pm() .367$ & $.101 \pm(1) .258$ & ()$\pm 1.2$ \\
\hline MV -52 & $5.67 \pm 1.45$ & $4.00 \pm 1.02$ & $-.183 \pm(1) .307$ & $-.105 \pm 0.181$ & $.6 \pm 2.4$ \\
\hline$M V-54$ & $3.39 \pm 1.19$ & $2.38 \pm 0.835$ & $.062 \pm(1) .337$ & $.039 \pm(0.210$ & $.5 \pm 3.2$ \\
\hline$M V-56$ & $2.12 \pm 0.942$ & $1.48 \pm 0.658$ & $-.280 \pm(1) .297$ & $-.156 \pm 0.17 \mathrm{i}$ & $-.2 \pm 1.6$ \\
\hline MV -61 & $4.15 \pm 1.27$ & $2.88 \pm 0.890$ & $.084 \pm 0.255$ &.$(045 \pm 0.139$ & ()$\pm 1.6$ \\
\hline
\end{tabular}


yttrium-90) in picocuries per liter, and as cesium-137 in picocuries per liter. Reporting of the concentrations of gross heta-particle radioactivity in either one of these ways is for reference purposes only and does not imply that the radioactivity is attributed to these specific isotopes. The average annual concentrations of strontium-9() and cesium-1.37 in public drinking-water supplies that produce a 4-mrem/yr dose are $8 \mathrm{pCi} / \mathrm{L}$ and $120 \mathrm{pCi} / \mathrm{L}$, respectively. Gross heta-particle radioactivity measurements should not be compared directly to these concentrations.

Gross heta-particle radioactivity was measured in both the dissolved and suspended fractions of the water samples analyzed by NWQL. Dissolved concentrations of gross heta-particle radioactivity reported as cesium-1.37 and as strontium-90) in equilibrium with yttrium-90) in 20 of the 21 water samples analyzed by NWQL exceeded the reporting levels (table 6); concentrations ranged from $2.53 \pm 0.8731011 .9 \pm 2.86 \mathrm{pCi} / \mathrm{L}$, and $1.93 \pm 0.666$ to $8.91 \pm 2.14 \mathrm{pCi} / \mathrm{L}$, respectively. Suspended concentrations of gross beta-particle radicactivity reported as cesium-137 and as strontium-90) in equilibrium with yttrium-90) in water samples analyzed hy NWQL from two sites exceeded the reporting level. Concentrations of cesium-137 and strontium-9() in equilibrium with yttrium-90) were $1.16 \pm() .625$ and $1.11 \pm() .597 \mathrm{pCi} / \mathrm{L}$, respectively, for $\mathrm{MV}-32$ and $(0.872 \pm 0.549$ and $0.823 \pm 0.518$, respectively, for MV-48. Total concentrations of gross heta-particle radioactivity reported as cesium-1.37 in five water samples analyzed by ISU exceeded the reporting levels (table 6); concent rations ranged from $7.2 \pm 4.21010 .4 \pm 5.0 \mathrm{pCi} / \mathrm{L}$.

\section{Total Uranium}

Uranium is a widely distributed element that has three naturally occurring radioactive isotopes: uranium-238, uranium-235, and uranium-2.34. These isotopes undergo a complex series of radioactive decay that results in their ultimate conversion to stable isotopes of lead (Haglund, 1972). Total uranium is a measurement of the combined concentrations of these three isotopes. Dissolved total uranium concentrations in all water samples analyzed by NWQL exceeded the reporting levels (table 7); concentrations ranged from $1.39 \pm 0.2(09$ to $6.37 \pm(1) .955 \mu \mathrm{g} / \mathrm{L}$. The proposed maximum contaminant level for total uranium is $20 \mu \mathrm{g} / \mathrm{L}$ (table 3).

\section{Radium}

Radium-224 and radium-228 are naturally occurring radioactive decay products of thorium-232; radium-226 is a naturally occurring decay product of uranium-238. Radium-224 was not detected in any of the water samples. Concentrations of radium-226 exceeded the reporting level in all the water samples analyzed by NWQL; concentrations ranged from (0.018 10.011 to $0.062 \pm 0.015 \mathrm{pCi} / \mathrm{L}$ (table 7). Concentrations of radium-228 in all the water samples analyzed by NWQL were less than the reporting level. The sum of radium-226 and radium-228 concentrations in all the water samples was less than the maximum contaminant level of $5 \mathrm{pCi} / \mathrm{L}$ (table 3 ).

\section{Cesium-137, Lead-212, Lead-214, Bismuth-214, and Potassium-40}

Gamma spectrometry involves using a series of detectors to simultaneously determine the concentrations of a variety of radionuclides by the identification of their characteristic gamma emissions. Total and suspended fractions of cesium-137 and suspended fractions of lead-212, lead-214, bismuth-214, and potassium-40) were identified in water samples. The NWQL reported the radionuclides as suspended fractions, whereas ISU reported them as total. 
Table 6.--Concentrations of gross beta-particle radioactivity in water from selected wells and springs, eastern Snake River Plain

Analyses were performed by the U.S. Geological Survey's National Water Quality Laboratory (NWQL) and the Idaho State University's (ISU) Environmental Monitoring Laboratory using a residue procedure. Analytical results and uncertainties-for example, $7.57 \pm 2 .(01$ - in picocuries per liter. Analytical uncertainties are reported as $2 \mathbf{s}$. Site identifier: see figure 2 for location of sites. Abbreviations: Sr-9()/Y-9()--strontium-90 in equilibrium with yttrium-9(). Symbols: * indicates quality assurance sample (MV-28 is a replicate of MV-24; MV-34 is a replicate of MV-40). -indicates no analysis was performed|

\begin{tabular}{|c|c|c|c|c|c|}
\hline $\begin{array}{c}\text { Site } \\
\text { identifier }\end{array}$ & $\begin{array}{l}\text { Dissolved as } \\
\text { cesium-137 } \\
\text { NWQL }\end{array}$ & $\begin{array}{c}\text { Dissolved as } \\
\text { Sr-90/Y-90 } \\
\text { NWQL }\end{array}$ & $\begin{array}{l}\text { Suspended as } \\
\text { cesium-137 } \\
\text { NWQL }\end{array}$ & $\begin{array}{l}\text { Suspended as } \\
\text { Sr-90/Y-90 } \\
\text { NWQL }\end{array}$ & $\begin{array}{c}\text { Total as } \\
\text { cesium-137 } \\
\text { ISU }\end{array}$ \\
\hline MV-(1)2 & $7.57 \pm 2 .(01$ & $5.43 \pm 1.22$ & $-(0.248 \pm() .487$ & $-(0.241 \pm 0.474$ & $5.8 \pm 4.4$ \\
\hline$M V-10$ & $9.67 \pm 2.23$ & $7.25 \pm 1.67$ & $.163 \pm 0.481$ & $.154 \pm 0.454$ & $4.7 \pm 4.4$ \\
\hline$M V-12$ & $7.43 \pm 1.78$ & $5.68 \pm 1.36$ & $.341 \pm 0.476$ & $.321 \pm 0.449$ & $8.7 \pm 4.6$ \\
\hline MV-16 & $3.99 \pm 1.27$ & $2.88 \pm 0.793$ & $.375 \pm 0.487$ & $.362 \pm(0.470$ & $7.2 \pm 4.2$ \\
\hline MV-19 & $4.70 \pm 1.40$ & $3.41 \pm 1.39$ & $.224 \pm 0.463$ & $.216 \pm 0.448$ & $7.6 \pm 4.4$ \\
\hline MV-24 & $10.6 \pm 2.59$ & $8.10 \pm 1.98$ & $.553 \pm 0.508$ & $.529 \pm 0.486$ & $10.4 \pm 5.0$ \\
\hline$M V^{\prime}-26$ & 5.4()$\pm 1.26$ & $4.10 \pm 0.958$ & $.136 \pm(1) .444$ & $.129 \pm 0.419$ & $.8 \pm 4.2$ \\
\hline MV-28* & $11.9 \pm 2.86$ & $8.91 \pm 2.14$ & $.059 \pm 0.468$ & $.057 \pm 0.456$ & $4.1 \pm 5.0$ \\
\hline MV-29 & $3.96 \pm 1.20$ & $2.95 \pm 1.08$ & $.392 \pm 0.483$ & $.370 \pm 0.456$ & $-1.2 \pm 4.2$ \\
\hline MV-32 & $8.15 \pm 1.91$ & $6.10 \pm 1.43$ & $1.16 \pm 0.625$ & $1.11 \pm 0.597$ & $5.1 \pm 4.6$ \\
\hline MV-34* & $4.36 \pm 1.25$ & $3.22 \pm 0.795$ & $-.182 \pm(1.496$ & $-.177 \pm 0.482$ & -- \\
\hline MV-40 & $4.11 \pm 1.19$ & $3 .(02 \pm 1) .756$ & $.207 \pm() .460$ & $.20(1) \pm(0.446$ & $-.5 \pm 4.0$ \\
\hline$M V-41$ & $7.33 \pm 1.89$ & $5.48 \pm 1.41$ & $.507 \pm 0.539$ & $.485 \pm 0.516$ & $4.5 \pm 4.6$ \\
\hline$M V-42$ & $.710 \pm 0.576$ & $.536 \pm 0.427$ & $.225 \pm 0.500$ & $.216 \pm 0.478$ & $1.6 \pm 4.2$ \\
\hline MV-45 & $4.45 \pm 1.30$ & $3.26 \pm 1.26$ & $.147 \pm 1) .466$ & $.142 \pm 0.451$ & $7.7 \pm 4.2$ \\
\hline$M V-48$ & $3.07 \pm 0.917$ & $2.39 \pm 0.714$ & $.872 \pm 0.549$ & $.823 \pm 0.518$ & $5.0 \pm 4.2$ \\
\hline$M V-49$ & $2.53 \pm 0.873$ & $1.93 \pm 0.666$ & $.278 \pm(1.492$ & $.27(1 \pm 0.478$ & $4.4 \pm 4.2$ \\
\hline MV -52 & $8.93 \pm 1.88$ & $6.75 \pm 1.42$ & $-.443 \pm(1) .462$ & $-.431 \pm 0.449$ & $4.5 \pm 4.4$ \\
\hline$M V-54$ & $9.19 \pm 2.12$ & $6.99 \pm 1.62$ & $.375 \pm(1) .481$ & $.354 \pm 0.454$ & $5.7 \pm 4.8$ \\
\hline MV -56 & $4.73 \pm 1.32$ & $3.40 \pm 10.816$ & $.34(1) \pm 0.48()$ & $.329 \pm 0.465$ & $.3 \pm 4.2$ \\
\hline MV-61 & $2.99 \pm 1.944$ & $2.29 \pm 0.722$ & $.84(0 \pm 0.570$ & $.814 \pm 0.552$ & $5.3 \pm 4.2$ \\
\hline
\end{tabular}


Table 7.--Concentrations of total uranium and selected radium isotopes in water from selected wells and springs, eastern Snake River Plain

Analyses were performed by the U.S. Geological Survey's National Water Quality Laboratory using the following methods: total uranium by extraction and laser-induced phosphorimetry; radium-226 by radon emanation; and radium-22 2 by separation and beta counting. Analytical results and uncertainties for example, $1.68 \pm(0.252$ in indicated units. Analytical uncertainties are reported as 2s. Site identifier: see figure 2 for location of sites. Abbreviations: $\mu \mathrm{g} / \mathrm{L}$--microgram per liter; pCi/L--picocurie per liter. Symbols: * indicates quality assurance sample (MV-28 is a replicate of MV-24; MV-34 is a replicate of MV-4())

\begin{tabular}{|c|c|c|c|}
\hline $\begin{array}{l}\text { Site } \\
\text { identifier }\end{array}$ & $\begin{array}{l}\text { Total uranium } \\
(\mu \mathrm{g} / \mathrm{L})\end{array}$ & $\begin{array}{l}\text { Radium-226 } \\
(\mathrm{pCi} / \mathrm{L})\end{array}$ & $\begin{array}{l}\text { Radium-228 } \\
\qquad(\mathrm{pCi} / \mathrm{L})\end{array}$ \\
\hline MV-1)2 & $1.68 \pm(1) .252$ & $(0.033 \pm 1) .(1) 9$ & (0.153\#).429 \\
\hline MV-10 & $1.59 \pm(1.239$ & $.036 \pm(1) .011$ & $.211 \pm 1.318$ \\
\hline$M V-12$ & $2.57 \pm 1) .385$ & $.036 \pm 1) .014$ & $.424 \pm(1) .356$ \\
\hline$M V-16$ & $1.56 \pm 1) .243$ & $.(1) 24 \pm 1) .(1)(18)$ & $.118 \pm(1) .341$ \\
\hline MV-19 & $2.11 \pm() .317$ &.$(128 \pm 0.0(1) 8$ & $.173 \pm(1.286$ \\
\hline$M V-24$ & $3.35 \pm 1) .5(1) 3$ &.$(13(1) \pm 1) .0(09$ & .6()$(0) \pm(1.574$ \\
\hline$M V-26$ & $1.64 \pm 0.245$ & $.033 \pm 1) .(1) 10$ & $.2(18 \pm(1) .324$ \\
\hline MV-28* & $3.31 \pm 1.497$ & $.(032 \pm 1) .(1) 12$ & $.113 \pm() .337$ \\
\hline MV-29 & $1.48 \pm() .222$ & $.(1) 28 \pm 1) .(1) 14$ & $.182 \pm(1.451$ \\
\hline MV-32 & $3.16 \pm() .473$ & $.021 \pm(1) .(1)(17$ & $.4(1) \pm(1.356$ \\
\hline MV $-34^{*}$ & $1.59 \pm(1.239$ & $.(128+1) .(1) 11$ & $.265 \pm(1) .3(1) 4$ \\
\hline$M V-40$ & $1.48 \pm(1) .221$ & $.(1) 27 \pm 0.0111$ & $.213 \pm(1) .312$ \\
\hline$M V-41$ & $6.37 \pm 10.955$ & $.062 \pm 0) .(1) 15$ & $.176 \pm(1) .345$ \\
\hline$M V-42$ & $1.39 \pm(1.209$ & $.(1) 31 \pm 0.012$ & $.195 \pm(1) .348$ \\
\hline$M V-45$ & $1.67 \pm() .25()$ & $.(0) 18 \pm(1) .(1) 11$ & $.336 \pm(1) .377$ \\
\hline$M V-48$ & $1.66 \pm(1.249$ & $.(1) 32 \pm(1) .0(1) 9$ & $.372 \pm(1.347$ \\
\hline$M V-49$ & $1.68 \pm 1) .252$ &.$(13(1) \pm 0.0(1) 8$ & $.110 \pm 0.366$ \\
\hline$M V-52$ & $3.41 \pm 1) .512$ &.$(139 \pm(1) .015$ & $.451 \pm(1) .4(1) 1$ \\
\hline$M V-54$ & $2.8 .5 \pm 1) .428$ &.$(13.5 \pm(1) .(1) 10$ &.$(196 \pm 0.396$ \\
\hline MV-56 & $1.55 \pm(1) .232$ &.$(13() \pm(1) .(0)(1)$ & $.261 \pm 0.305$ \\
\hline MV-61 & $2.11 \pm 0.317$ &.$(139 \pm(1) .010$ & .22()$\pm(1) .326$ \\
\hline
\end{tabular}


Cesium-137 is a fission product of uranium-235, uranium-233, or plutonium-239. None of the samples analyzed by NWQL had concentrations of cesium-137 that exceeded the reporting level (table 8). One sample analyzed by ISU had a concentration equal to the reporting level. MV-28, a quality assurance replicate of $\mathrm{MV}-24$, had a concentration of $3 \pm 2 \mathrm{pCi} / \mathrm{L}$.

Lead-212 is a decay product of radium-224 in the thorium-2.32 decay series. Lead-212 was identified in four water samples; three samples had concentrations greater than the reporting levels and anged from $0.227 \pm 0.13 .3$ (1) (0.259.t). $1125 \mathrm{pCi} / \mathrm{L}$ (table 8).

Lead-214 is an intermediate isotope in the uranium-238 decay series. Lead-214 was identified in one water sample, MV-32, at a concentration less than the reporting level (table 8).

Bismuth-214 is a naturally occurring member of the uranium-238 decay series. Bismuth-214 was identified in the sample from MV-26 at a concentration of $0.461 \pm 0.235 \mathrm{pCi} / \mathrm{L}$, which exceeded the reporting level.

Potassium makes up approximately 2.6 percent of the Earth's continental crust, and about 0.0119 percent of all potassium is the naturally occurring radioactive isotope potassium-40 (Kretz, 1972). Potassium-40) was identified in eight water samples; four samples had concentrations greater than the reporting levels and ranged from $5.05 \pm 1.45$ to $7.382 \pm 3.157 \mathrm{pCi} / \mathrm{L}$ (table 8 ).

\section{INORGANIC CONSTITUENTS}

Water samples were analyzed for selected inorganic constituents. These constituents included trace elements, common ions, nutrients, and cyanide. In this report, reporting levels established for these constituents are not to be confused with reporting levels and analytical method detection limits for selected radionuclides. The reporting level for inorganic constituents is the lowest measured concentration of a constituent that may be reliably reported using a given analytical method (Pritt and Jones, 1989).

\section{Trace Elements}

Water samples were collected and analyzed by NWQL and IDHWL for selected dissolved trace elements including aluminum, arsenic, barium, beryllium, cadmium, chromium, cobalt, copper, iron, lead, lithium, manganese, mercury, molybdenum, nickel, selenium, silver, strontium, vanadium, and zinc. Water samples also were analyzed for total and hexavalent chromium by NWQL, and total arsenic, barium, beryllium, cadmium, chromium, lead, mercury, selenium, and silver by IDHWL. Maximum contaminant levels and reporting levels for the trace elements are shown on table 9. Concentrations of dissolved trace elements are shown on table 10, and concentrations of total trace elements are shown on table 11.

Aluminum-Concentrations in 10 samples analyzed by NWQL were equal to or greater than the reporting level and ranged from $101040 \mu \mathrm{g} / \mathrm{L}$. The proposed secondary maximum contaminant level is $50 \mu \mathrm{g} / \mathrm{L}$.

Arsenic- Concentrations of dissolved arsenic in all samples analyzed by NWQL were equal to or greater than the reporting level and ranged from 1 to $5 \mu \mathrm{g} / \mathrm{L}$. Concentrations of dissolved and total arsenic in all samples analyzed by IDHWL were less than the reporting level of $10 \mu \mathrm{g} / \mathrm{L}$. The maximum contaminant level is $50 \mu \mathrm{g} / \mathrm{L}$.

Barium.-Concentrations of dissolved barium in all samples except MV-42 analyzed by NWQL were greater than the reporting level and ranged from $1810150 \mu \mathrm{g} / \mathrm{L}$. Concentrations of dissolved and total harium 
Table 8.-Concentrations of cesium-137, lead-212, lead-214, bismuth-214, and potassium-40 in water from selected wells and springs, eastern Snake River Plain

IAnalyses were performed by the U.S. Geological Survey's National Water Quality Laboratory (NWQL) and the Idaho State University's (ISU) Environmental Monitoring Laboratory using gamma spectrometry. Analytical results and uncertainties from NWQL for example, ().(1)38 $\pm(0.101$ - are for suspended concentrations in $\mathrm{pCi} / \mathrm{L}$ (picocuries per liter). Analytical results and uncertainties from ISU are for total concentrations in $\mathrm{pCi} / \mathrm{L}$. Analytical uncertainties are reported as $2 \mathrm{~s}$. Site identifier: see figure 2 for location of sites. Symbols: * indicates quality assurance sample (MV-28 is a replicate of MV-24; MV-34 is a replicate of MV-4()); $\bullet$ indicates that the radionuclide was not detected in that sample; -- indicates no analysis availablel

\begin{tabular}{|c|c|c|c|c|c|c|}
\hline $\begin{array}{c}\text { Site } \\
\text { identifier }\end{array}$ & $\begin{array}{c}\text { Cesium-137 } \\
\text { NWQL }\end{array}$ & $\begin{array}{c}\text { Cesium-137 } \\
\text { ISL }\end{array}$ & $\begin{array}{c}\text { Lead-212 } \\
\text { NWQL }\end{array}$ & $\begin{array}{c}\text { Lead-214 } \\
\text { NWQL }\end{array}$ & $\begin{array}{c}\text { Bismuth-214 } \\
\text { NWQL }\end{array}$ & $\begin{array}{c}\text { Potassium-40) } \\
\text { NWQL }\end{array}$ \\
\hline$M V-() 2$ & $(0.038 \pm 0.101$ & $1 \pm 2$ & $\bullet \bullet$ & $\bullet \bullet$ & $\bullet \bullet$ & $\bullet \bullet$ \\
\hline MV-10 & $.065 \pm 0.082$ & ()$\pm 2$ & $\bullet$ & $\bullet \bullet$ & $\bullet \bullet$ & $\bullet \bullet$ \\
\hline$M V-12$ &.$-(05() \pm() .092$ & $0 \pm 2$ & $\bullet$ & $\bullet \bullet$ & $\bullet$ & $\bullet$ \\
\hline MV-16 & $-.0(08 \pm 10.089$ & $2 \pm 2$ & $0.259 \pm 0.1125$ & $\bullet$ & $\bullet \bullet$ & $\bullet$ \\
\hline MV-19 & $-.066 \pm(1) .114$ & $2 \pm 2$ & $.257 \pm(0.153$ & $\bullet$ & $\bullet \bullet$ & $5.721 \pm 3.124$ \\
\hline$M V-24$ & $.057 \pm 0.115$ & $1 \pm 2$ & $.227 \pm(0.133$ & $\bullet \bullet$ & $\bullet$ & $\bullet \bullet$ \\
\hline MV-26 &.$-(127 \pm 0.118$ & $1 \pm 2$ & $\bullet$ & $\bullet$ & $0.461 \pm 0.235$ & $7.291 \pm 3.131$ \\
\hline MV-28* &.$-(139 \pm(1) .096$ & $3 \pm 2$ & $\bullet$ & $\bullet \bullet$ & $\bullet$ & $\bullet$ \\
\hline MV-29 & .02()$\pm(1) .114$ & $2 \pm 2$ & .2() $3 \pm() .140$ & $\bullet$ & $\bullet$ & $\bullet \bullet$ \\
\hline MV -32 &.$(121 \pm(0.093$ & $1 \pm 2$ & $\bullet$ & $(0.3()() \pm() .251$ & $\bullet \bullet$ & $\bullet \bullet$ \\
\hline MV-34* & $-.063 \pm(1.094$ & -- & $\bullet$ & $\bullet \bullet$ & $\bullet \bullet$ & $\bullet$ \\
\hline MV-40 & $.014 \pm(1) .097$ & $1 \pm 2$ & $\bullet \bullet$ & $\bullet \bullet$ & $\bullet \bullet$ & $3.271 \pm 2.471$ \\
\hline MV-41 & $.0(06 \pm 0.088$ & $(1) \pm 2$ & $\bullet \bullet$ & $\bullet \bullet$ & $\bullet \bullet$ & $\bullet$ \\
\hline MV -42 & $-.(012 \pm 1) .(092$ & () \pm 2 & $\bullet \bullet$ & $\bullet \bullet$ & $\bullet \bullet$ & $3.142 \pm 2.514$ \\
\hline$M V-45$ & $-.121 \pm(1) .116$ & $1 \pm 2$ & $\bullet \bullet$ & $\bullet$ & $\bullet \bullet$ & $\bullet$ \\
\hline$M V-48$ &.$-(12 \pm 10.08$ & $2 \pm 2$ & $\bullet \bullet$ & $\bullet \bullet$ & $\bullet \bullet$ & $5.05 \pm 1.45$ \\
\hline MV-49 &.$-(010 \pm(0.085$ & $0 \pm 2$ & $\bullet \bullet$ & $\bullet$ & $\bullet \bullet$ & $\bullet$ \\
\hline$M V-52$ & -() $21 \pm(0.094$ & $2 \pm 2$ & $\bullet \bullet$ & $\bullet \bullet$ & $\bullet$ & $3.715 \pm 2.674$ \\
\hline MV-54 & $.05(1) \pm() .092$ & $1 \pm 2$ & $\bullet$ & $\bullet \bullet$ & $\bullet \bullet$ & $\bullet$ \\
\hline$M V-56$ & 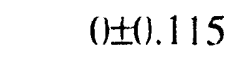 & $(1 \pm 2$ & $\bullet \bullet$ & $\bullet \bullet$ & $\bullet \bullet$ & $7.382 \pm 3.157$ \\
\hline MV -61 & $-.(036 \pm 1) .(1997$ & $1 \pm 2$ & $\bullet \bullet$ & $\bullet \bullet$ & $\bullet \bullet$ & $1.28 \pm 2.11$ \\
\hline
\end{tabular}


Table 9.- Maximum contaminant levels and reporting levels of selected trace elements in drinking water

The maximum contaminant levels are for total measurements and were established pursuant to the recommendations of the U.S. Environmental Protection Agency (1989, p. 547) for community water systems and are included for comparison purposes only. Proposed maximum contaminant levels shown in parentheses are from U.S. Environmental Protection Agency (199)a). Proposed secondary and secondary maximum contaminant levels shown in brackets are from U.S. Environmental Frotection Agency (199()a), -- indicates that a maximum contaminant level has not been established for that chemical constituent; $\bullet$ indicates analysis not requested. Units are in $\mu \mathrm{g} / \mathrm{L}$ (microgram per liter). Reporting levels for the U.S. Geological Survey's National Water Quality Laboratory (NWQL) are from Pritt and Jones (1989). Reporting levels for the Idaho Department of Health and Welfare Laboratory (IDHWL) are from J. Dodds (written commun., 1991)|

$\begin{array}{ccc}\text { Maximum } & \text { Reporting level } & \text { Reporting level } \\ \text { Constituent } & \text { NWQL } & \text { IDHWL }\end{array}$

Aluminum

Arsenic

Barium

Beryllium

Cadmium

Chromium, total

Chromium, dissolved

Chromium, hexavalent

Cobalt

Copper

Iron

Lead

Lithium

Manganese

Mercury

Molybdenum

Nickel

Selenium

Silver

Strontium

Vanadium

Zinc

\section{0}

1

2

10)

$\begin{array}{ll}.5 & 5 \\ 1 & 1 \\ 1 & 3\end{array}$

5

1

10)

3

1

5

\section{4}

1

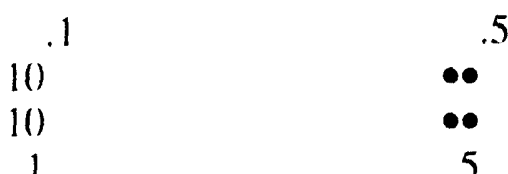

5

1 
Table 10.-Concentrations of dissolved trace elements in water from selected wells and springs, eastern Snake River Plain

IAnalyses were performed by the U.S. Geological Survey's National Water Quality Laboratory (NWQL) and the Idaho Department of Health and Welfare Laboratory (IDHWL). Analytical results in $\mu \mathrm{g} / \mathrm{L}$ (microgram per liter); < indicates the concentration was less than the respective reporting level. Site identifier: see figure 2 for location of sites. Symbols: * indicates quality assurance sample (MV-28 is a replicate of MV-24; MV-34 is a replicate of MV-40); MV-62 is an equipment blank); -indicates no analysis was performedl

\begin{tabular}{|c|c|c|c|c|c|c|c|}
\hline $\begin{array}{c}\text { Site } \\
\text { identifier }\end{array}$ & $\begin{array}{l}\text { Aluminum } \\
\text { NWQL }\end{array}$ & $\begin{array}{l}\text { Arsenic } \\
\text { NWQL }\end{array}$ & $\begin{array}{l}\text { Arsenic } \\
\text { IDHWL }\end{array}$ & $\begin{array}{l}\text { Barium } \\
\text { NWQL }\end{array}$ & $\begin{array}{l}\text { Barium } \\
\text { IDHWL }\end{array}$ & $\begin{array}{l}\text { Beryllium } \\
\text { NWQL }\end{array}$ & $\begin{array}{l}\text { Beryllium } \\
\text { IDWHL }\end{array}$ \\
\hline MV-02 & 10 & 3 & $<10$ & 68 & $<100$ & $<0.5$ & $<5$ \\
\hline$M V-10$ & 10 & 2 & $<10$ & 85 & $<100$ & $<.5$ & $<5$ \\
\hline MV-12 & 40 & 2 & $<10$ & 56 & $<100$ & $<.5$ & $<5$ \\
\hline$M V-16$ & $<10$ & 2 & $<10$ & 25 & $<100$ & .7 & $<5$ \\
\hline MV-19 & 10 & 2 & $<10$ & 30 & $<100$ & $<.5$ & $<5$ \\
\hline MV-24 & $<10$ & 3 & $<10$ & 140 & 130 & $<.5$ & $<5$ \\
\hline MV-26 & $<10$ & 2 & $<10$ & 27 & $<100$ & $<.5$ & $<5$ \\
\hline MV-28* & $<10$ & 3 & $<10$ & 150 & 180 & $<.5$ & $<5$ \\
\hline MV-29 & 20 & 2 & $<10$ & 22 & $<100$ & $<.5$ & $<5$ \\
\hline MV-32 & 20 & 2 & $<10$ & 85 & $<100$ & .6 & $<5$ \\
\hline MV-34* & $<10$ & 2 & -- & 18 & $\cdots$ & $<.5$ & -- \\
\hline MV-40 & 20 & 2 & $<10$ & 18 & $<100$ & $<.5$ & $<5$ \\
\hline MV-41 & $<10$ & 3 & $<10$ & 80 & $<100$ & $<.5$ & $<5$ \\
\hline MV-42 & $<10$ & 3 & $<10$ & $<2$ & $<100$ & .9 & $<5$ \\
\hline MV -45 & $<10$ & 2 & $<10$ & 25 & $<100$ & $<.5$ & $<5$ \\
\hline MV-48 & 10 & 1 & $<10$ & 50 & $<100$ & $<.5$ & $<5$ \\
\hline MV-49 & 10 & 1 & $<10$ & 54 & $<100$ & $<.5$ & $<5$ \\
\hline MV -52 & $<10$ & 5 & $<10$ & 74 & $<100$ & $<.5$ & $<5$ \\
\hline MV-54 & 10 & 2 & $<10$ & 120 & 110 & $<.5$ & $<5$ \\
\hline MV-56 & $<10$ & 2 & $<10$ & 25 & $<100$ & .6 & $<5$ \\
\hline MV-61 &.- & -- & $<10$ & -- & $<100$ & -- & $<5$ \\
\hline MV-62* & -- & -- & $<10$ & -- & $<100$ & - & $<5$ \\
\hline
\end{tabular}


Table 10.-Concentrations of dissolved trace elements in water from selected wells and springs, eastern Snake River Plain--Continued

\begin{tabular}{|c|c|c|c|c|c|}
\hline \multirow[b]{2}{*}{$\begin{array}{l}\text { Site } \\
\text { identifier }\end{array}$} & \multirow[b]{2}{*}{$\begin{array}{l}\text { Cadmium } \\
\text { NWQL }\end{array}$} & \multirow[b]{2}{*}{$\begin{array}{l}\text { Cadmium } \\
\text { IDHWL }\end{array}$} & \multicolumn{3}{|c|}{ Chromium } \\
\hline & & & $\begin{array}{l}\text { dissolved } \\
\text { NWQL }\end{array}$ & $\begin{array}{l}\text { dissolved } \\
\text { IDHWL }\end{array}$ & $\begin{array}{c}\text { hexavalent } \\
\text { NWQL }\end{array}$ \\
\hline MV-02 & $<1$ & $<1$ & $<5$ & $<3$ & $<1$ \\
\hline MV-10 & $<1$ & $<1$ & $<5$ & $<3$ & $<1$ \\
\hline MV-12 & $<1$ & $<1$ & $<5$ & $<3$ & $<1$ \\
\hline MV-16 & $<1$ & $<1$ & $<5$ & $<3$ & $<1$ \\
\hline MV-19 & $<1$ & $<1$ & $<5$ & $<3$ & $<1$ \\
\hline MV-24 & $<1$ & $<1$ & $<5$ & $<3$ & $<1$ \\
\hline MV-26 & $<1$ & $<1$ & $<5$ & $<3$ & $<1$ \\
\hline MV-28* & $<1$ & $<1$ & $<5$ & $<3$ & $<1$ \\
\hline MV-29 & $<1$ & $<1$ & $<5$ & 3 & $<1$ \\
\hline MV-32 & $<1$ & $<1$ & $<5$ & $<3$ & $<1$ \\
\hline MV-34* & $<1$ & $<1$ & $<5$ & -- & $<1$ \\
\hline MV -40 & $<1$ & $<1$ & $<5$ & $<3$ & $<1$ \\
\hline MV-41 & $<1$ & $<1$ & $<5$ & $<3$ & $<1$ \\
\hline MV -42 & $<1$ & $<1$ & $<5$ & $<3$ & $<1$ \\
\hline$M V-45$ & $<1$ & $<1$ & $<5$ & $<3$ & $<1$ \\
\hline MV -48 & 2 & -- & $<5$ & 3 & 1 \\
\hline MV-49 & 3 & $<1$ & $<5$ & $<3$ & 1 \\
\hline MV-52 & $<1$ & $<1$ & $<5$ & $<3$ & $<1$ \\
\hline MV-54 & 1 & $<1$ & $<5$ & $<3$ & $<1$ \\
\hline MV-56 & $<1$ & $<1$ & $<5$ & $<3$ & $<1$ \\
\hline MV-61 & -- & $<1$ & -- & $<3$ & -- \\
\hline MV $-62^{*}$ & -- & $<1$ & -- & $<3$ & -- \\
\hline
\end{tabular}


Table 10.-Concentrations of dissolved trace elements in water from selected wells and springs, eastern Snake River Plain--Continued

\begin{tabular}{|c|c|c|c|c|c|c|}
\hline $\begin{array}{c}\text { Site } \\
\text { identifier }\end{array}$ & $\begin{array}{l}\text { Cobalt } \\
\text { NWQL }\end{array}$ & $\begin{array}{l}\text { Copper } \\
\text { NWQL }\end{array}$ & $\begin{array}{c}\text { Iron } \\
\text { NWQL }\end{array}$ & $\begin{array}{c}\text { Lead } \\
\text { NWQL }\end{array}$ & $\begin{array}{l}\text { Lead } \\
\text { IDHWL }\end{array}$ & $\begin{array}{l}\text { Lithium } \\
\text { NWQL }\end{array}$ \\
\hline MV-02 & $<3$ & $<10$ & 9 & $<1$ & $<5$ & 43 \\
\hline MV-10 & $<3$ & $<10$ & 3 & $<1$ & $<5$ & 48 \\
\hline$M V-12$ & $<3$ & $<10$ & 4 & $<1$ & $<5$ & 43 \\
\hline MV-16 & $<3$ & $<10$ & $<3$ & $<1$ & $<5$ & 25 \\
\hline MV-19 & $<3$ & $<10$ & 3 & $<1$ & $<5$ & 30 \\
\hline MV-24 & $<3$ & $<10$ & 6 & $<1$ & $<5$ & 51 \\
\hline MV-26 & $<3$ & $<10$ & 30 & $<1$ & $<5$ & 31 \\
\hline MV-28* & $<3$ & $<10$ & 5 & $<1$ & $<5$ & 51 \\
\hline MV-29 & $<3$ & $<10$ & 140 & $<1$ & $<5$ & 22 \\
\hline MV-32 & $<3$ & $<10$ & 31 & $<1$ & $<5$ & 38 \\
\hline MV-34* & $<3$ & $<10$ & 8 & 2 & -- & 13 \\
\hline MV-40 & $<3$ & $<10$ & 33 & 1 & $<5$ & 13 \\
\hline MV-41 & $<3$ & $<10$ & $<3$ & $<1$ & $<5$ & 7 \\
\hline MV -42 & $<3$ & $<10$ & $<3$ & $<1$ & $<5$ & $<4$ \\
\hline MV -45 & $<3$ & $<10$ & $<3$ & $<1$ & $<5$ & 15 \\
\hline$M V-48$ & $<3$ & $<10$ & 5 & 1 & $<5$ & $<4$ \\
\hline MV-49 & $<3$ & 10 & 26 & $<1$ & $<5$ & 5 \\
\hline MV-52 & $<3$ & $<10$ & 6 & $<1$ & $<5$ & 24 \\
\hline MV-54 & $<3$ & $<10$ & 53 & $<1$ & $<5$ & 55 \\
\hline MV-56 & $<3$ & $<10$ & 19 & $<1$ & $<5$ & 27 \\
\hline MV-61 & -- & -- & - & -- & $<5$ & -- \\
\hline MV-62* & -- & - & -- & -- & $<5$ & -- \\
\hline
\end{tabular}


Table 10.-Concentrations of dissolved trace elements in water from selected wells and springs, eastern Snake River Plain--Continued

\begin{tabular}{|c|c|c|c|c|c|c|c|}
\hline $\begin{array}{c}\text { Site } \\
\text { identifier }\end{array}$ & $\begin{array}{l}\text { Manganese } \\
\text { NWQL }\end{array}$ & $\begin{array}{l}\text { Mercury } \\
\text { NWQL }\end{array}$ & $\begin{array}{l}\text { Mercury } \\
\text { IDHWL }\end{array}$ & $\begin{array}{l}\text { Molybdenum } \\
\text { NWQL }\end{array}$ & $\begin{array}{l}\text { Nickel } \\
\text { NWQL }\end{array}$ & $\begin{array}{l}\text { Selenium } \\
\text { NWQL }\end{array}$ & $\begin{array}{c}\text { Selenium } \\
\text { IDHWL }\end{array}$ \\
\hline $\mathrm{MV}-02$ & $<1$ & $<0.1$ & $<0.5$ & $<10$ & $<10$ & $<1$ & $<5$ \\
\hline MV-10 & $<1$ & $<.1$ & $<.5$ & $<10$ & $<10$ & 1 & $<5$ \\
\hline MV-12 & $<1$ & $<.1$ & $<.5$ & $<10$ & $<10$ & 1 & $<5$ \\
\hline MV-16 & $<1$ & $<.1$ & $<.5$ & $<10$ & $<10$ & $<1$ & $<5$ \\
\hline MV-19 & $<1$ & $<.1$ & $<.5$ & $<10$ & $<10$ & $<1$ & $<5$ \\
\hline MV-24 & $<1$ & $<.1$ & $<.5$ & $<10$ & $<10$ & 1 & $<5$ \\
\hline MV-26 & $<1$ & $<.1$ & $<.5$ & $<10$ & $<10$ & $<1$ & $<5$ \\
\hline MV-28* & $<1$ & $<.1$ & $<.5$ & $<10$ & $<10$ & 1 & $<5$ \\
\hline MV-29 & 1 & $<.1$ & $<.5$ & $<10$ & $<10$ & $<1$ & $<5$ \\
\hline MV-32 & 1 & $<.1$ & $<.5$ & $<10$ & $<10$ & $<1$ & $<5$ \\
\hline MV-34* & $<1$ & $<.1$ & -- & $<10$ & $<10$ & $<1$ & -- \\
\hline MV-40 & $<1$ & $<.1$ & $<.5$ & $<10$ & $<10$ & $<1$ & $<5$ \\
\hline MV-41 & $<1$ & $<.1$ & $<.5$ & $<10$ & $<10$ & $<1$ & $<5$ \\
\hline MV-42 & $<1$ & $<.1$ & $<.5$ & $<10$ & $<10$ & $<1$ & $<5$ \\
\hline MV-45 & $<1$ & $<.1$ & $<.5$ & $<10$ & $<10$ & $<1$ & $<5$ \\
\hline MV-48 & $<1$ & $<.1$ & $<.5$ & $<10$ & $<10$ & 1 & $<5$ \\
\hline MV-49 & 2 & $<.1$ & $<.5$ & $<10$ & $<10$ & $<1$ & $<5$ \\
\hline MV-52 & $<1$ & $<.1$ & $<.5$ & $<10$ & $<10$ & $<1$ & $<5$ \\
\hline MV-54 & 3 & $<.1$ & $<.5$ & $<10$ & $<10$ & $<1$ & $<5$ \\
\hline MV-56 & 1 & $<.1$ & $<.5$ & $<10$ & $<10$ & $<1$ & $<5$ \\
\hline MV-61 & -- & -- & $<.5$ & -- & -- & -- & $<5$ \\
\hline MV-62* & -- & -- & $<.5$ & -- & -- & -- & $<5$ \\
\hline
\end{tabular}


Table 10.--Concentrations of dissolved trace elements in water from selected wells and springs, eastern Snake River Plain--Continued

\begin{tabular}{lccccc}
\hline $\begin{array}{c}\text { Site } \\
\text { identifier }\end{array}$ & $\begin{array}{c}\text { Silver } \\
\text { NWQL }\end{array}$ & $\begin{array}{c}\text { Silver } \\
\text { IDHWL }\end{array}$ & $\begin{array}{c}\text { Strontium } \\
\text { NWQL }\end{array}$ & $\begin{array}{c}\text { Vanadium } \\
\text { NWQL }\end{array}$ & $\begin{array}{c}\text { Zinc } \\
\text { NWQL }\end{array}$ \\
\hline & & & & & \\
MV-(02 & 2 & $<1$ & 340 & 7 & 23 \\
MV-10 & $<1$ & $<1$ & $4(0)$ & $<6$ & $<3$ \\
MV-12 & $<1$ & $<1$ & 360 & 6 & 21 \\
MV-16 & $<1$ & $<1$ & 230 & 9 & 3 \\
MV-19 & $<1$ & $<1$ & 230 & 8 & $<3$ \\
MV-24 & $<1$ & $<1$ & 430 & 6 & 3 \\
MV-26 & $<1$ & $<1$ & 220 & 7 & 8 \\
MV-28* & $<1$ & $<1$ & 440 & $<6$ & 7 \\
MV-29 & $<1$ & $<1$ & 180 & 8 & 7 \\
MV-32 & $<1$ & $<1$ & 370 & $<6$ & 72 \\
MV-34* & $<1$ & -- & 160 & 8 & 7 \\
MV-40 & $<1$ & $<1$ & 160 & 8 & 4 \\
MV-41 & $<1$ & $<1$ & 370 & 12 & 3 \\
MV-42 & 2 & $<1$ & 4 & 12 & 4 \\
MV-45 & 1 & $<1$ & 220 & 10 & $<3$ \\
MV-48 & $<1$ & $<1$ & 230 & $<6$ & 110 \\
MV-49 & $<1$ & $<1$ & 190 & $<6$ & 180 \\
MV-52 & $<1$ & $<1$ & 260 & 11 & 45 \\
MV-54 & 2 & $<1$ & 480 & 7 & 39 \\
MV-56 & $<1$ & $<1$ & 210 & 8 & 43 \\
MV-61 & -- & $<1$ & -- & -- & -- \\
MV-62* & -- & $<1$ & -- & -- & -- \\
\hline & & & & & \\
\hline
\end{tabular}


Table 11.-Concentrations of total trace elements in water from selected wells and springs, eastern Snake River Plain

[Analyses were performed by U.S. Geological Survey's National Water Quality Laboratory (NWQL) and the Idaho Department of Health and Welfare Laboratory (IDHWL). Analytical results in $\mu \mathrm{g} / \mathrm{L}$ (microgram per liter); < indicates the concentration was less than the respective reporting level. Site identifier: see figure 2 for location of sites. Symbols: * indicates quality assurance sample (MV-28 is a replicate of MV-24; MV-34 is a replicate of MV-40); --indicates no analysis was performed]

\begin{tabular}{|c|c|c|c|c|c|c|c|c|c|c|}
\hline $\begin{array}{l}\text { Site } \\
\text { identi- } \\
\text { fier }\end{array}$ & $\begin{array}{l}\text { Arsenic } \\
\text { IDHWL }\end{array}$ & $\begin{array}{l}\text { Barium } \\
\text { IDHWL }\end{array}$ & $\begin{array}{l}\text { Beryl- } \\
\text { lium } \\
\text { IDHWL }\end{array}$ & $\begin{array}{l}\text { Cad- } \\
\text { mium } \\
\text { IDHWL }\end{array}$ & $\begin{array}{l}\text { Chro- } \\
\text { mium } \\
\text { NWQL }\end{array}$ & $\begin{array}{l}\text { Chro- } \\
\text { mium } \\
\text { IDHWL }\end{array}$ & $\begin{array}{l}\text { Lead } \\
\text { IDHWL }\end{array}$ & $\begin{array}{l}\text { Mer- } \\
\text { cury } \\
\text { IDHWL }\end{array}$ & $\begin{array}{l}\text { Selen- } \\
\text { ium } \\
\text { IDHWL }\end{array}$ & $\begin{array}{l}\text { Silver } \\
\text { IDHWL }\end{array}$ \\
\hline$M V-() 2$ & $<10$ & $<100$ & $<5$ & $<1$ & 2 & $<3$ & $<5$ & $<0.5$ & $<5$ & $<1.0$ \\
\hline MV-10 & $<10$ & $<100$ & $<5$ & $<1$ & 4 & $<3$ & $<5$ & $<.5$ & $<5$ & $<1.0$ \\
\hline MV-12 & $<10$ & $<100$ & $<5$ & $<1$ & 1 & $<3$ & $<5$ & $<.5$ & $<5$ & $<1.0$ \\
\hline MV-16 & $<10$ & $<100$ & $<5$ & $<1$ & 4 & $<3$ & $<5$ & $<.5$ & $<5$ & $<1.0$ \\
\hline MV-19 & $<10$ & $<100$ & $<5$ & $<1$ & $<1$ & 4 & $<5$ & $<.5$ & $<5$ & $<1.0$ \\
\hline MV-24 & $<10$ & 120 & $<5$ & $<1$ & 3 & $<3$ & $<5$ & $<.5$ & $<5$ & $<1.0$ \\
\hline MV-26 & $<10$ & $<100$ & $<5$ & $<1$ & $<1$ & $<3$ & $<5$ & $<.5$ & $<5$ & $<1.0$ \\
\hline MV-28* & $*<10$ & 150 & $<5$ & $<1$ & 3 & $<3$ & $<.5$ & $<.5$ & $<5$ & $<1.0$ \\
\hline MV-29 & $<10$ & $<100$ & $<5$ & $<1$ & 4 & $<3$ & $<5$ & $<.5$ & $<5$ & $<1 .()$ \\
\hline MV-32 & $<10$ & $<100$ & $<5$ & $<1$ & $<1$ & $<3$ & $<5$ & $<.5$ & $<5$ & $<1.0$ \\
\hline $\mathrm{MV}-34^{*}$ & $\begin{array}{ll}* & --\end{array}$ & -- & -- & -- & 2 & -- & -- & -- & -- & -- \\
\hline MV-40 & $<10$ & $<100$ & $<5$ & $<1$ & 2 & $<3$ & $<5$ & $<.5$ & $<5$ & $<1.0$ \\
\hline MV-41 & $<10$ & $<10()$ & $<5$ & $<1$ & 2 & $<3$ & $<5$ & $<.5$ & $<5$ & $<1.0$ \\
\hline MV-42 & $<10$ & $<100$ & $<5$ & $<1$ & 6 & $<3$ & $<5$ & $<.5$ & $<5$ & $<1.0$ \\
\hline MV -45 & $<10$ & $<100$ & $<5$ & $<1$ & 9 & $<3$ & $<5$ & $<.5$ & $<5$ & $<1.0$ \\
\hline$M V-48$ & $<10$ & $<100$ & $<5$ & $<1$ & 2 & 4 & $<5$ & $<.5$ & $<5$ & $<1 .()$ \\
\hline$M V-49$ & $<10$ & $<100$ & $<5$ & $<1$ & 1 & $<3$ & $<5$ & $<.5$ & $<5$ & $<1.0$ \\
\hline MV-52 & $<10$ & 130 & $<5$ & $<1$ & 1 & $<3$ & $<5$ & $<.5$ & $<5$ & $<1.0$ \\
\hline MV-54 & $<10$ & $<100$ & $<5$ & $<1$ & 2 & $<3$ & $<5$ & $<.5$ & $<5$ & $<1 .()$ \\
\hline MV-56 & $<10$ & $<100$ & $<5$ & $<1$ & $<1$ & $<3$ & $<5$ & $<.5$ & $<5$ & $<1.0$ \\
\hline MV-61 & $<10$ & $<100$ & $<5$ & $<1$ & -- & 5 & 5 & $<.5$ & $<5$ & $<1.0$ \\
\hline
\end{tabular}


in three samples analyzed by IDHWL were greater than the reporting level and ranged from 110 to $180 \mu \mathrm{g} / \mathrm{L}$ and $120 \mathrm{to} 150 \mu \mathrm{g} / \mathrm{L}$, respectively. The maximum contaminant level is 1,000$) \mu \mathrm{g} / \mathrm{L}$.

Beryllium.-- Concentrations of dissolved heryllium in four samples analyzed by NWQL were greater than the reporting level and ranged from $0.6100 .9 \mu \mathrm{g} / \mathrm{L}$. Concentrations of dissolved and total beryllium in all samples analyzed hy IDHWL were less than the reporting level of $5 \mu \mathrm{g} / \mathrm{L}$. The proposed maximum contaminant level is $1 \mu \mathrm{g} / \mathrm{L}$.

Cadmium.-Concentrations of dissolved cadmium in three samples analyzed by NWQL were equal to or greater than the reporting level and ranged from 1 to $3 \mu \mathrm{g} / \mathrm{L}$. Concentrations of dissolved and total cadmium in all samples analyzed by IDHWL were less than the reporting level of $1 \mu \mathrm{g} / \mathrm{L}$. The maximum contaminant level is $10 \mu \mathrm{g} / \mathrm{L}$.

Chromium--Chromium analyses included total, dissolved, and hexavalent. Concentrations of total chromium in 16 samples analyzed by NWQL equaled or exceeded the reporting level and ranged from 1 to $9 \mu \mathrm{g} / \mathrm{L}$; the maximum contaminant level is $50 \mu \mathrm{g} / \mathrm{L}$. All the samples analyzed by the NWQL had dissolved chromium concentrations less than the reporting level of $5 \mu \mathrm{g} / \mathrm{L}$. Hexavalent chromium concentrations analyzed by NWQL in samples from MV-48 and MV-49 were equal to the reporting level of $1 \mu \mathrm{g} / \mathrm{L}$. Concentrations of total chromium in three samples analyzed by IDHWL exceeded the reporting level and ranged from 4 to $5 \mu \mathrm{g} / \mathrm{L}$. Dissolved chromium concentrations analyzed by IDHWL in samples from MV-29 and MV-48 were cqual to the reporting level of $3 \mu \mathrm{g} / \mathrm{L}$.

Cubalt_-All the samples analyzed by NWQL had dissolved cobalt concentrations less than the reporting level of $3 \mu \mathrm{g} / \mathrm{L}$.

Copper_-Concentrations of dissolved copper in 19 samples analyzed by NWQL were less than the reporting level of $10 \mu \mathrm{g} / \mathrm{L}$. One sample (MV-49) had a concentration of $10 \mu \mathrm{g} / \mathrm{L}$. The proposed maximum contaminant level for copper is $1,300 \mu \mathrm{g} / \mathrm{L}$.

Iron.-Concentrations of dissolved iron in 16 samples analyzed by NWQL equaled or exceeded the reporting level and ranged from 3 to $140 \mu \mathrm{g} / \mathrm{L}$; the secondary maximum contaminant level is $300 \mu \mathrm{g} / \mathrm{L}$.

Lead.-Dissolved lead concentrations in three samples analyzed by NWQL equaled or exceeded the reporting level and ranged from 1 to $2 \mu \mathrm{g} / \mathrm{L}$. Concentrations of dissolved lead in all samples analyzed by IDHWL were less than the reporting level of $5 \mu \mathrm{g} / \mathrm{L}$. One sample (MV-61) analyzed by IDHWL had a total lead concentration of $5 \mu \mathrm{g} / \mathrm{L}$. The maximum contaminant level is $50 \mu \mathrm{g} / \mathrm{L}$.

Lithium.-Concentrations of dissolved lithium in 18 samples analyzed by NWQL exceeded the reporting level and ranged from $51055 \mu \mathrm{g} / \mathrm{L}$.

Manganese-Concentrations of manganese in five samples equaled or exceeded the reporting level and ranged from 1 to $3 \mu \mathrm{g} / \mathrm{L}$; the secondary maximum contaminant level is $50 \mu \mathrm{g} / \mathrm{L}$.

Mercury.-All the samples analyzed by NWQL had mercury concentrations less than the reporting level of $0.1 \mu \mathrm{g} / \mathrm{L}$. All the samples analyzed by IDHWL had mercury concentrations less than the reporting level of $0.5 \mu \mathrm{g} / \mathrm{L}$. The maximum contaminant level for mercury is $2 \mu \mathrm{g} / \mathrm{L}$.

Molybdenum.-All the samples analyzed hy NWQL had molyhdenum concentrations less than the reporting level of $10 \mu \mathrm{g} / \mathrm{L}$.

Nickel.-All the samples analyzed by NWQL had nickel concentrations less than the reporting level of $10 \mu \mathrm{g} / \mathrm{L}$. The proposed maximum contaminant level for nickel is $100 \mu \mathrm{g} / \mathrm{L}$. 
Selenium_-Dissolved selenium concentrations in five samples analyzed by NWQL were equal to the reporting level of $1 \mu \mathrm{g} / \mathrm{L}$. All the samples analyzed by IDHWL had dissolved and total selenium concentrations less than the reporting level of $5 \mu \mathrm{g} / \mathrm{L}$. The maximum contaminant level is $10 \mu \mathrm{g} / \mathrm{L}$.

Silver-Concentrations of dissolved silver in four samples analyzed by NWQL were equal to or greater than the reporting level and ranged from 1 to $2 \mu \mathrm{g} / \mathrm{L}$. All the samples analyzed by IDHWL had dissolved and total silver concentrations less than the reporting level of $1 \mu \mathrm{g} / \mathrm{L}$. The maximum contaminant level for silver is $50 \mu \mathrm{g} / \mathrm{L}$.

Strontium- - Strontium concentrations in all samples analyzed by NWQL excecled the reporting level and ranged from 4 to $480 \mu \mathrm{g} / \mathrm{L}$.

Vanadium_-Concentrations of vanadium in 15 samples analyzed by NWQL equaled or exceeded the reporting level and ranged from $61012 \mu \mathrm{g} / \mathrm{L}$.

Zinc:-Concentrations of zinc in 17 samples analyzed by NWQL equaled or excecded the reporting level and ranged from $3 \mathrm{to} 180 \mu \mathrm{g} / \mathrm{L}$.

\section{Common lons}

Water samples were analyzed by NWQL for dissolved common ions including bromide, calcium, chloride, fluoride, magnesium, potassium, silica, sodium, and sulfate. Water samples were analyzed by IDHWL for total chloride, fluoride, sodium, and sulfate. Maximum contaminant levels or secondary maximum contaminant levels and reporting levels for these ions are shown on table 12. Concentrations of dissolved common ions are shown on table 13, and concentrations of total common ions are shown on table 14.

Bromide - Concentrations of dissolved bromide in all samples analyzed by NWQL exceeded the reporting level and ranged from $0.02100 .25 \mathrm{mg} / \mathrm{L}$.

Calcium.--Dissolved calcium concentrations in all samples analyzed hy NWQL exceeded the reporting level and ranged from $0.681074 \mathrm{mg} / \mathrm{L}$.

Chloride--Dissolved chloride concentrations in all samples analyzed by NWQL exceded the reporting level and ranged from $2.410110 \mathrm{mg} / \mathrm{L}$. Total chloride concentrations in all samples analyzed by IDHWL exceeded the reporting level and ranged from 4 (1) $1(0) 1 \mathrm{mg} / \mathrm{L}$. The secondary maximum contaminant level is $250 \mathrm{mg} / \mathrm{L}$.

Fluoride.-Concentrations of dissolved fluoride in all samples analyod by NWQL exceded the reporting level and ranged from 0.2 to $0.6 \mathrm{mg} / \mathrm{L}$. Concentrations of total fluoride in all samples analyzed by IDHWL exceeded the reporting level and ranged from (0.21 (1) $0.95 \mathrm{mg} / \mathrm{L}$. The maximum contaminant level is $4 \mathrm{mg} / \mathrm{L}$.

Magnesium,-Dissolved magnesium concentrations in all samples analyzed by NWQL exceeded the reporting level and ranged from $(0.2610 .34 \mathrm{mg} / \mathrm{L}$.

Potassium_-Concentrations of dissolved potassium in all samples analyzed by NWQL exceeded the reporting level and ranged from $0.3108 .3 \mathrm{mg} / \mathrm{L}$.

Silica_-Dissolved silica concentrations in all samples analyzed by NWQL were greater than the reporting level and ranged from $23 \mathrm{to} 40 \mathrm{mg} / \mathrm{L}$.

Sodium_-Concentrations of dissolved sodium in all samples analyzed by NWQL were greater than the reporting level and ranged from $8.610110 \mathrm{mg} / \mathrm{L}$. Concentrations of total sodium in all samples analyzed by 
Table 12.--Maximum contaminant levels and reporting levels of selected common ions in drinking water

IThe maximum contaminant levels are for total measurements and were established pursuant to the recommendations of the U.S. Environmental Protection Agency (1989, p. 547) for community water systems and are included for comparison purposes only. Secondary maximum contaminant levels shown in brackets-are from U.S. Environmental Protection Agency (1989, 199(a); -- indicates that maximum contaminant level has not been established for that chemical constituent; $\bullet$ indicates analysis not requested. Units are in mg/L (milligram per liter). Reporting levels for the U.S.

Geological Survey's National Water Quality Laboratory (NWQL) are from Pritt and Jones (1989). Reporting levels for the Idaho Department of Health and Welfare Laboratory (IDHWL) are from J. Dodds (written commun., 1991)1

\begin{tabular}{cccc}
\hline Maximum & Reporting level & Reporting level \\
Constituent & contaminant level & IDHWL
\end{tabular}

Bromide

Calcium

Chloride

Fluoride

Magnesium

Potassium

Silica

Sodium ${ }^{1}$

Sulfate

${ }^{1}$ Idaho Department of Health and Welfare (1989) recommends an optimum concentration of $20 \mathrm{mg} / \mathrm{L}$.

\section{--}

(0.01

.(12

|250]

.1

0) .89

--

4

.1

.01

12]

--

.01

.1

.01

.2

.1

[250]

1

5 
Table 13.-Concentrations of dissolved common ions in water from selected wells and springs, eastern Snake River Plain

IAnalyses were performed by the U.S. Geological Survey's National Water Quality Laboratory. Analytical results in $\mathrm{mg} / \mathrm{L}$ (milligram per liter). Site identifier: see figure 2 for location of sites. Symbols: * indicates quality assurance sample (MV-28 is a replicate of MV-24; MV-34 is a replicate of $\mathrm{MV}-4(0)]$

\begin{tabular}{|c|c|c|c|c|c|c|c|c|c|}
\hline $\begin{array}{l}\text { Site } \\
\text { identi- } \\
\text { fier }\end{array}$ & $\begin{array}{l}\text { Bro- } \\
\text { mide }\end{array}$ & $\begin{array}{l}\text { Cal- } \\
\text { cium }\end{array}$ & $\begin{array}{l}\text { Chlo- } \\
\text { ride }\end{array}$ & $\begin{array}{l}\text { Fluo- } \\
\text { ride }\end{array}$ & $\begin{array}{l}\text { Magne- } \\
\text { sium }\end{array}$ & $\begin{array}{l}\text { Potas- } \\
\text { sium }\end{array}$ & $\begin{array}{l}\text { Sil- } \\
\text { ica }\end{array}$ & $\begin{array}{l}\text { So- } \\
\text { dium }\end{array}$ & $\begin{array}{l}\text { Sul- } \\
\text { fate }\end{array}$ \\
\hline MV-()2 & 0.09 & 53 & 50 & 0.5 & 21 & 6.5 & 37 & 40 & 52 \\
\hline$M V-10$ & .18 & 64 & 77 & .5 & 26 & 6.8 & 34 & 56 & 71 \\
\hline$M V-12$ & .17 & 66 & 71 & .5 & 23 & 5.3 & 33 & 45 & 79 \\
\hline MV-16 & .04 & 38 & 16 & .6 & 18 & 3.4 & 35 & 23 & 35 \\
\hline$M V-19$ & .07 & 44 & 32 & .6 & 18 & 3.5 & 33 & 23 & 41 \\
\hline$M V-24$ & .25 & 73 & 100 & .4 & 34 & 8.3 & 34 & 88 & 90 \\
\hline MV-26 & .08 & 44 & 35 & .6 & 17 & 3.8 & 31 & 24 & 40 \\
\hline MV-28* & .25 & 74 & 110 & .4 & 34 & 8.2 & 34 & 89 & 95 \\
\hline MV-29 & .04 & 32 & 17 & .6 & 15 & 3.4 & 34 & 18 & 33 \\
\hline MV -32 & .13 & 66 & 49 & .4 & 25 & 5.0 & 37 & 42 & 57 \\
\hline MV - $34^{*}$ & .03 & 31 & 13 & .4 & 15 & 3.2 & 33 & 18 & 27 \\
\hline MV-40 &.$(1) 3$ & 31 & 13 & .5 & 15 & 3.3 & 33 & 18 & 26 \\
\hline$M V-41$ & .09 & 71 & 33 & .5 & 32 & 4.6 & 4() & 50 & 71 \\
\hline$M V-42$ & .04 & .68 & 16 & .5 & .26 & .3 & 35 & 110 & 36 \\
\hline MV-45 & .03 & 36 & 11 & .4 & 18 & 3.7 & 34 & 20 & 25 \\
\hline MV-48 & .04 & 43 & 14 & .2 & 14 & 2.3 & 23 & 8.7 & 23 \\
\hline MV-49 & .02 & 50 & 2.4 & .2 & 15 & 2.2 & 28 & 8.6 & 14 \\
\hline MV -52 & .08 & 50 & 34 & .4 & 20) & 5.4 & 40 & 46 & 57 \\
\hline MV-54 & .19 & 74 & 74 & .4 & 29 & 7.6 & 36 & 60 & 74 \\
\hline MV-56 & .05 & 37 & 25 & .6 & 17 & 3.3 & 33 & 22 & 34 \\
\hline
\end{tabular}


Table 14.-Concentrations of total common ions in water from selected wells and springs, eastern Snake River Plain

|Analyses were performed by the Idaho Department of Health and Welfare Laboratory. Analytical results in $\mathrm{mg} / \mathrm{L}$ (milligram per liter). Site identifier: see figure 2 for location of sites. Symbols: * indicates quality assurance sample (MV-28 is replicate of MV-24) I

\begin{tabular}{|c|c|c|c|c|}
\hline $\begin{array}{l}\text { Site } \\
\text { identifier }\end{array}$ & Chloride & Fluoride & Sodium & Sulfate \\
\hline$M V_{-12}$ & 46 & 0.54 & 33 & 48 \\
\hline$M V-10$ & 73 & .56 & 52 & 69 \\
\hline$M V-12$ & 63 & .51 & 41 & 75 \\
\hline$M V-16$ & 17 & .63 & 19 & 35 \\
\hline MV-19 & 29 &.$\$ 7$ & 22 & 40 \\
\hline$M V-24$ & 101 & .41 & 84 & 102 \\
\hline MV-26 & 34 & .61 & 23 & 47 \\
\hline MV-28* & 101 & .44 & 80 & 102 \\
\hline MV-29 & 15 & .63 & 16 & 30 \\
\hline MV-32 & 46 & .45 & 34 & 72 \\
\hline$M V-40$ & 12 & .50 & 16 & 24 \\
\hline$M V-41$ & 32 & .50 & 42 & 72 \\
\hline$M V-42$ & 18 & .53 & 92 & 36 \\
\hline$M V-45$ & 13 & .49 & 15 & 29 \\
\hline MV-48 & 13 & .26 & 7 & 22 \\
\hline MV-49 & 4 & .21 & 8 & 14 \\
\hline MV-52 & 32 & .53 & 43 & 65 \\
\hline MV-54 & 72 & .45 & 50 & 77 \\
\hline MV-56 & 21 & .61 & 18 & 37 \\
\hline MV-61 & 22 & .95 & 15 & 19 \\
\hline
\end{tabular}


IDHWL were greater than the reporting level and ranged from 7 to $92 \mathrm{mg} / \mathrm{L}$. IDHW (1989) recommended an optimum level of $20 \mathrm{mg} / \mathrm{L}$ sodium for public drinking-water supplics.

Sulfate-Concentrations of dissolved sulfate in all samples analyzed by NWQL exceeded the reporting level and ranged from $14 \mathrm{to} 95 \mathrm{mg} / \mathrm{L}$. Concentrations of total sulfate in all samples analyzed by IDHWL were greater than the reporting level and ranged from $14 \mathrm{lo}) 1(12 \mathrm{mg} / \mathrm{L}$. The secondary maximum contaminant level for sulfate is $250 \mathrm{mg} / \mathrm{L}$.

\section{Nutrients and Cyanide}

Water samples were analyzed by NWQL for dissolved ammonia (as nitrogen), nitrite (as nitrogen), nitrite plus nitrate (as nitrogen), orthophosphate (as phosphorus), and cyanide. The maximum contaminant levels proposed by the U.S. Environmental Protection Agency (1989 and 199)b) and the reporting levels for nitrite, nitrite plus aitrate, and cyanide are shown on table 15. A maximum contaminant level has not been established or proposed for ammonia or orthophosphate.

Concentrations of nutrients are shown on table 16. Ammonia concentrations in two samples (MV-26 and MV-56) equaled or exceeded the reporting level at concentrations of $0 .(01$ and $0 .(12 \mathrm{mg} / \mathrm{L}$, respectively. Concentrations of nitrite in all samples were less than the reporting level of (0.)1 $\mathrm{mg} / \mathrm{L}$. Concentrations of nitrite plus nitrate in all samples exceeded the reporting level and ranged from $0.51105 .7 \mathrm{mg} / \mathrm{L}$; the maximum contaninant level is $10 \mathrm{mg} / \mathrm{L}$ (table 15). Orthophosphate concentrations as phosphorus in 17 samples equaled or exceeded the reporting level and ranged from $0.01 \mathrm{lo}(0.07 \mathrm{mg} / \mathrm{L}$. Concentrations of cyanide in all samples were less than the reporting level of $0.01 \mathrm{mg} / \mathrm{L}$.

\section{ORGANIC COMPOUNDS}

Water samples were analyzed by NWQL for selected organic compounds. These compounds included dissolved organic carbon, surfactants, purgeable organic compounds, insecticides, polychlorinated compounds, and herbicides. Reporting levels established for these constituents (Pritt and Jones, 1989) are not be confused with reporting levels and analytical method detection limits for selected radionuclides.

\section{Dissolved Organic Carbon}

Water samples were analyzed for dissolved organic carbon (DOC), and concentrations are shown on table 16. Concentrations of DOC in all samples were greater than the reporting level of $0.1 \mathrm{mg} / \mathrm{L}$, and ranged from 0.4 to $2.4 \mathrm{mg} / \mathrm{L}$; no maximum contaminant level has been established.

\section{Surfactants}

Water samples were analyzed for surfactants (table 16). Concentrations of surfactants in 17 samples equaled or exceeded the reporting level and ranged from $0.01100 .08 \mathrm{mg} / \mathrm{L}$; the secondary maximum contaminant level is $0.5 \mathrm{mg} / \mathrm{L}$ (U.S. Environmental Protection Agency, 1989).

\section{Purgeable Organic Compounds}

Samples from all sites were analyzed for 36 purgeable organic compounds. The maxinum contaminant levels and reporting levels for these compounds are shown on table 17. Only one of the compounds, 
Table 15.-Maximum contaminant levels and reporting levels for selected nutrients, cyanide, dissolved organic carbon, and surfactants in drinking water

IThe maximum contaminant levels were established pursuant to the recommendations of the U.S. Environmental Protection Agency (1989 and 199()a) for community water systems and are included for comparison purposes only. Proposed maximum contaminant levels--shown in parentheses-are from U.S. Environmental Protection Agency (199()a); -- indicates that a maximum contaminant level has not been established or proposed for that constituent. Units are mg/L (milligram per liter).

Reporting levels are from Pritt and Jones (1989)]

\section{Maximum}

Constituent contaminant level

Reporting level

Ammonia (as nitrogen)

0.01

Nitrite (as nitrogen)

Nitrite plus nitrate

(as nitrogen)

Orthophosphate

(as phosphorus)

$\begin{array}{ll}- & .01\end{array}$

Cyanide

Dissolved organic carbon

$\begin{array}{ll}- & .1\end{array}$

Surfactants 1

$-$

${ }^{1}$ Secondary maximum contaminant level for surfactants is $0.5 \mathrm{mg} / \mathrm{L}$ (U.S.

Environmental Protection Agency, 1989, p. 656). 
Table 16.-Concentrations of nutrients, cyanide, dissolved organic carbon, and surfactants in water from selected wells and springs, eastern Snake River Plain

|Analyses were performed by U.S. Geological Survey's National Water Quality Laboratory. Analytical results in $\mathrm{mg} / \mathrm{L}$ (milligram per liter); < indicates the concentration was less than the respective reporting level. Site identifier: see figure 2 for location of sites. Symbols: * indicates quality assurance sample (MV-28 is a replicate of MV-24; MV-34 is a replicate of MV-40); LS indicates sample was lost by laboratoryl

\begin{tabular}{|c|c|c|c|c|c|c|c|}
\hline $\begin{array}{l}\text { Site } \\
\text { identi- } \\
\text { fier }\end{array}$ & $\begin{array}{c}\text { Ammonia } \\
\text { (as nitrogen) }\end{array}$ & $\begin{array}{c}\text { Nitrite } \\
\text { (as nitrogen) }\end{array}$ & $\begin{array}{c}\text { Nitrite } \\
\text { plus } \\
\text { nitrate } \\
\text { (as nitrogen) }\end{array}$ & $\begin{array}{l}\text { Ortho- } \\
\text { phosphate } \\
\text { (as phos- } \\
\text { phorus) }\end{array}$ & Cyanide & $\begin{array}{l}\text { Dissolved } \\
\text { organic } \\
\text { carbon }\end{array}$ & $\begin{array}{c}\text { Sur- } \\
\text { factants }\end{array}$ \\
\hline MV-02 & $<0.01$ & $<0.01$ & 1.1 & $<0 .(01$ & $<0.01$ & 0.6 & 0.02 \\
\hline MV-10 & $<.01$ & $<.01$ & 2.7 & $<.01$ & $<.01$ & 1.3 & .04 \\
\hline MV-12 & $<.01$ & $<.01$ & 1.7 & .02 & $<.01$ & 1.2 & .02 \\
\hline MV-16 & $<.01$ & $<.01$ & .95 & .02 & $<.01$ & .7 & .01 \\
\hline MV-19 & $<.01$ & $<.01$ & 1.9 & .02 & $<.01$ & .7 &.() 3 \\
\hline MV-24 & $<.01$ & $<.01$ & 5.7 & .02 & $<.01$ & 2.3 & .07 \\
\hline$M V-26$ & .01 & $<.01$ & .89 & .02 & $<.01$ & .6 & .02 \\
\hline MV-28* & $<.01$ & $<.01$ & 5.7 & .02 & $<.01$ & 2.4 & .08 \\
\hline MV-29 & $<.01$ & $<.01$ & .51 & .01 & $<.01$ & .4 & $<.01$ \\
\hline MV-32 & $<.() 1$ & $<.01$ & 3.2 & .02 & $<.01$ & 1.1 & .04 \\
\hline MV-34* & $<.01$ & $<.01$ & .67 & .02 & $\mathrm{LS}$ & .4 & $<.01$ \\
\hline MV-40 & $<.01$ & $<.01$ & .69 & .02 & $<.01$ & .5 & $<.01$ \\
\hline$M V-41$ & $<.01$ & $<.01$ & 2.6 & .07 & $<.01$ & 1.5 & .03 \\
\hline MV -42 & $<.01$ & $<.01$ & 1.3 & .04 & $<.01$ & .6 & .02 \\
\hline MV -45 & $<.01$ & $<.01$ & 1.0 & .01 & $<.(01$ & .6 & .01 \\
\hline$M V-48$ & $<.01$ & $<.01$ & .77 & $<.01$ & $<.01$ & .8 & .02 \\
\hline MV-49 & $<.01$ & $<.01$ & 1.7 & .02 & $<.01$ & .5 & .03 \\
\hline MV-52 & $<.01$ & $<.01$ & 1.8 & .02 & $<.01$ & 1.2 & .02 \\
\hline MV-54 & $<.01$ & $<.01$ & 4.3 & .02 & $<.01$ & 1.4 & .05 \\
\hline MV-56 & .02 & $<.01$ & .93 & .02 & $<.01$ & .5 & .02 \\
\hline
\end{tabular}


Table 17.--Maximum contaminant levels and reporting levels of selected purgeable organic compounds in drinking water

Analyses were performed by the U.S. Geological Survey's National Water Quality Laboratory (NWQL) using an analytical method equivalent to U.S. Environmental Protection Agency method 524.2. The reporting level for all compounds is (0.2 micrograms per liter (Pritt and Jones, 1989). Maximum contaminant level: * indicates that total trihalomethanes-which include bromoform, chloroform, dibromochloromethane, and dichlorobromomethane-in community water systems serving 10,0()(1 or more persons cannot exceed 100) micrograms per liter (U.S. Environmental Protection Agency, 1989, p. 548). Proposed maximum contaminant levels--shown in parenthesesare from J. Rodin (U.S. Environmental Protection Agency, written commun., 1989) and U.S.

Environmental Protection Agency (199()a, b). -- indicates that a maximum contaminant level has not been established or proposed for that compound. Units are $\mu \mathrm{g} / \mathrm{L}$ (microgram per liter)]

\begin{tabular}{|c|c|c|c|}
\hline Compound & $\begin{array}{c}\text { Maximum } \\
\text { contaminant } \\
\text { level }\end{array}$ & Compound & $\begin{array}{c}\text { Maximum } \\
\text { contaminant } \\
\text { level }\end{array}$ \\
\hline Benzene & 5.0 & Ethylbenzene & $(700)$ \\
\hline Bromoform & $*$ & 1,3-Dichloropropene & -- \\
\hline Carbon tetrachloride & 5.0 & Cis-1,3-Dichloropropene & -- \\
\hline Chlorobenzene & $(100)$ & Styrene & $(10.0)$ \\
\hline Chloroethane & -- & Methyl bromide & -- \\
\hline 2-Chloroethyl vinyl ether & -- & Trans-1,3-Dichloropropene & -- \\
\hline Chloroform & $*$ & Chloromethane & -- \\
\hline Dibromochloromethane & $*$ & Dichlorobromomethane & $*$ \\
\hline Methylene chloride & -- & Toluene & $(2,000)$ \\
\hline 1,1,2,2-Tetrachloroethane & -- & Trichlorofluoromethane & -- \\
\hline 1,2-Dichloroethane & 5.0 & Tetrachloroethylene & $(5.0)$ \\
\hline 1,2-Dichlorobenzene & $(600)$ & 1,3-Dichlorobenzene & -- \\
\hline 1,4-Dichlorobenzene & 75 & Trichloroethylene & 5.0 \\
\hline $1,1,1$-Trichloroethane & 200 & 1,2-trans-Dichloroethylene & $(100)$ \\
\hline 1,1,2-Trichloroethane & $(5)$ & Dichlorodifluoromethane & -- \\
\hline 1,2-Dibromoethane & -- & 1,2-Dichloropropane & $(5.0)$ \\
\hline 1,1-Dichloroethane & -- & Xylenes, mixed & $(10,000)$ \\
\hline Vinyl chloride & 2.0 & 1,1-Dichloroethylene & 7.0 \\
\hline
\end{tabular}


1,1,1 trichloroethane, was detected in two water samples. The 1,1,1-trichloroethane concentrations from MV-29 and MV-45 were 0.2 and $0.3 \mu \mathrm{g} / \mathrm{L}$, respectively; the maximum contaminant level is $200 \mu \mathrm{g} / \mathrm{L}$.

\section{Insecticides and Polychlorinated Compounds}

Water samples were analyzed for concentrations of 10 carbamate insecticides, 11 organophosphorus insecticides, 15 organochlorine insecticides, gross PCB's, and gross PCN's. The maximum contaminant levels and reporting levels for these compounds are shown on table 18. None of the measured organic compounds exceeded their respective reporting levels. The laboratory had low surrogate recovery on two samples (MV-19 and MV-54) analyzed for organochlorine insecticides; the data should be considered "qualified" and revicwed with caution.

\section{Herbicides}

Concentrations of 12 triazine herbicides and 4 chlorophenoxy-acid herbicides were determined by the NWQL. Maximum contaminant levels and reporting levels for these compounds are shown on table 19. Two samples (MV-40) and MV-56) and a quality assurance replicate (MV-34) had concentrations of 2, 4-D equal to the reporting level of $0.01 \mu \mathrm{g} / \mathrm{L}$. None of the other herbicides exceeded their respective reporting levels.

\section{FECAL COLIFORM BACTERIA}

Water samples were analyzed for fecal coliform bacteria by the IDHWL at Twin Falls, Idaho. Coliformdensity tests indicated one sample, MV-19, had a count of nine colonies per $100 \mathrm{~mL}$. The other samples had zero counts per $100 \mathrm{~mL}$. The maximum contaminant level for public drinking-water supplies for bacteria is based on the presence or absence of total coliforms (zero colonies per $1(0) \mathrm{mL}$ ) (U.S. Environmental Protection Agency, 199()a). Because fecal coliform is one of the species included in the total coliform test, one sample exceeded the maximum contaminant level for total coliform.

\section{SUMMARY}

The USGS and the Idaho Department of Water Resources, in response to a request from the U.S. Department of Energy, sampled 18 sites as part of a long-term project to monitor water quality of the Snake River Plain aquifer from the southem boundary of the Idaho National Enginecring Laboratory to the Hagerman area. Water samples were collected and analyzed for manmade pollutants and naturally occurring constituents. The samples were collected from six irrigation wells, seven domestic wells, two springs, one stock well, one dairy well, and one observation well. Quality assurance samples also were collected and analyzed. The samples were analyzed for selected radion clides, inorganic constituents, organic compounds, and bacteria.

Radon-222 was detected at concentrations exceeding the reporting level at 10 sites, but none exceeded the proposed maximum contaminant level. Concentrations of strontium- 9() in all samples were less than the reporting level. All samples analyzed by NWQL had concentrations of tritium greater than the reporting level, but none exceeded the maximum contaminant level for drinking water. All samples analyzed by ISU had concentrations of tritium less than the reporting level.

Concentrations of dissolved gross alpha-particle radioactivity in all samples exceeded the reporting level; none exceeded the U.S. Environmental Protection Agency maximum contaminant level. Concentrations of 
Table 18.-Maximum contaminant levels and reporting levels of selected insecticides and gross polychlorinated compounds in drinking water

IThe maximum contaminant levels were established pursuant to the recommendations of the U.S. Environmental Protection Agency (1989, p. 548) for community water systems and are included for comparison purposes only. Proposed maximum contaminant levels-shown in parentheses-are from U.S. Environmental Protection Agency (1990a). -- indicates that a maximum contaminant level has not been established or proposed for that compound. Units are in $\mu \mathrm{g} / \mathrm{L}$ (microgram per liter). Reporting levels are from Pritt and Jones (1989)]

Carbamate insecticides: reporting level is $0.5 \mu \mathrm{g} / \mathrm{L}$

\begin{tabular}{llll} 
Insecticide & $\begin{array}{l}\text { Maximum } \\
\text { contam- } \\
\text { inant } \\
\text { level }\end{array}$ & Insecticide & $\begin{array}{l}\text { Maximum } \\
\text { contam- } \\
\text { inant } \\
\text { level }\end{array}$ \\
\hline Aldicarb & $(10)$ & 3-Hydroxycarbofuran & -- \\
Aldicarb sulfone & $(40)$ & Methomyl & -- \\
Aldicarb sulfoxide & $(10)$ & 1-Naphthol & -- \\
Carbaryl (Sevin) & - & Oxamyl & $(200)$ \\
Carbofuran & $(40)$ & Propham & --
\end{tabular}

Organophosphorus insecticides: reporting level is $0.01 \mathrm{\mu g} / \mathrm{L}$

\begin{tabular}{llll} 
& $\begin{array}{l}\text { Maximum } \\
\text { contam- } \\
\text { inant } \\
\text { Insecticide }\end{array}$ & Insecticide & $\begin{array}{l}\text { Maximum } \\
\text { contam- } \\
\text { inant } \\
\text { level }\end{array}$ \\
\hline $\begin{array}{l}\text { Chlorpyrifos; Dursban } \\
\text { Diazinon }\end{array}$ & -- & Methyl parathion & -- \\
Disulfoton & -- & Methyl trithion & -- \\
Ethion & -- & Parathion & -- \\
Fonofos & -- & Phorate & -- \\
Malathion & -- & Trithion & --
\end{tabular}


Table 18.-Maximum contaminant levels and reporting levels of selected insecticides and gross polychlorinated compounds in drinking water--Continued

Organochlorine insecticides: reporting level is $0.01 \mu \mathrm{g} / \mathrm{L}$ except for chlordane and perthane $(0.1 \mathrm{\mu g} / \mathrm{L})$, and toxaphene $(1.0 \mathrm{\mu g} / \mathrm{L})$

\begin{tabular}{lllc} 
Insecticide & $\begin{array}{l}\text { Maximum } \\
\text { contam- } \\
\text { inant } \\
\text { level }\end{array}$ & Insecticide & $\begin{array}{l}\text { Maximum } \\
\text { contam- } \\
\text { inant } \\
\text { level }\end{array}$ \\
\hline Aldrin & & Heptachlor & $(0.4)$ \\
Chlordane & -- & Heptachlor epoxide & $(.2)$ \\
DDD & $(2.0)$ & Lindane & 4.0 \\
DDE & -- & Methoxychlor & $(.2)$ \\
DDT & -- & 100 \\
Dieldrin & -- & Mirex & $(400)$ \\
Endosulfan & -- & -- \\
Endrin & -- & Perthane & -- \\
& -2 & Toxaphene & 5.0
\end{tabular}

Gross polychlorinated compounds: reporting level is $0.1 \mathrm{Hg} / \mathrm{L}$

Compound

Maximum contaminant

Gross polychlorinated biphenyls (PCB's) level

Gross polychlorinated naphthalenes (PCN's) 
Table 19.-Maximum contaminant levels and reporting levels of triazines and chlorophenoxy-acid herbicides in drinking water

IThe maximum contaminant levels were established pursuant to the recommendations of the U.S. Environmental Protection Agency (1989) for community water systems and are included for comparison purposes only. Proposed maximum contaminant levels--shown in parentheses-are from U.S. Environmental Protection Agency (1990a). -- indicates that a maximum contaminant level has not been established or proposed for that compound. Units are in $\mu \mathrm{g} / \mathrm{L}$ (microgram per liter) Reporting levels are from Pritt and Jones (1989).I

Triazines and other nitrogen-containing herbicides: reporting level is $0.1 \mathrm{\mu g} / \mathrm{L}$

\begin{tabular}{llll} 
Herbicide & $\begin{array}{l}\text { Maximum } \\
\text { contam- } \\
\text { inant } \\
\text { level }\end{array}$ & Herbicide & $\begin{array}{c}\text { Maximum } \\
\text { contam- } \\
\text { inant } \\
\text { level }\end{array}$ \\
\hline Alachlor & $(2.0)$ & Prometon & -- \\
Ametryn & -- & Prometryn & -- \\
Atrazine & $(3.0)$ & Propazine & - \\
Cyanazine & - & Simazine & $(1.0)$ \\
Metolachlor & -- & Simetryn & -- \\
Metribuzin & -- & Trifluralin & --
\end{tabular}

Chlorophenoxy-acid herbicides: reporting level is $0.01 \mu \mathrm{g} / \mathrm{L}$

\begin{tabular}{llll} 
Herbicide & $\begin{array}{l}\text { Maximum } \\
\text { contam- } \\
\text { inant } \\
\text { level }\end{array}$ & Herbicide & $\begin{array}{c}\text { Maximum } \\
\text { contam- } \\
\text { inant } \\
\text { level }\end{array}$ \\
\hline $2,4-\mathrm{D}$ & $100,(70)$ & Silvex & $10,(50)$ \\
$2,4-\mathrm{DP}$ & -- & $2,4,5-\mathrm{T}$ & -
\end{tabular}


dissolved gross beta-particle radioactivity in all but one sample, suspended gross beta-particle radioactivity in two samples, and total gross beta-particle radioactivity in five samples exceeded the reporting level. Total uranium concentrations exceeded the reporting level in all water samples, but none exceeded the proposed maximum contaminant level. Radium-226 concentrations exceeded the reporting level in all samples; radium-228 concentrations were less than the reporting level in all samples; none exceeded the established maximum contaminant levels for radium isotopes. Five radionuclides were identified using gamma spectroscopy. Cesium-137 was identified in all the samples, lead-212 in four samples, lead-214 in one sample, bismuth-214 in one sample, and potassium-40 in eight samples. Concentrations of cesium-1.37 in one sample, lead-212 in three samples, bismuth-214 in one sample, and potassium-40) in four samples, exceeded the reporting level.

All the samples contained one or more dissolved trace clements and common ions in eoncent rations greater than the reporting levels. No samples exceeded an established maximum contaminant level.

Concentrations of ammonia (as nitrogen) in water samples from (wo sites exceeded the reporting level. Concentrations of nitrite plus nitrate (as nitrogen) in all the water samples exceeded the reporting level. Concentrations of orthophosphate (as phosphorus) in 17 of the water samples excecded the reporting level. Concentrations of nitrite (as nitrogen) and cyanide in all samples were less than the reporting level. Nutrient concentrations did not exceed established maximum contaminant levels.

Concentrations of dissolved organic carbon exceeded the reporting level in all the samples. Surfactants in 17 water samples exceeded the reporting level but did not exceed secondary maximum contaminant levels. Concentrations of 1,1,1-1richloroethane exceeded the reporting level in two water samples. No carbamate insecticides, organophosphorus insecticides, organochlorine insecticides, gross PCB's, or gross PCN's were detected at concentrations exceeding their respective reporting levels. Concentrations of 2, 4-D were equal to the reporting level in two samples and a quality assurance replicate.

A water sample from one site had fecal coliform bacteria counts that exceeded the U.S. Environmental Protection Agency's maximum contaminant level.

\section{SELECTED REFERENCES}

American Public Health Association and Water Pollution Control Federation, 1985, Standard methods for the examination of water and wastewater: Washington, D.C., American Public Health Association, 1,268 p.

Bartholomay, R.C., Edwards, D.D., and Campbell, L.J., 1992, Radionuclides, inorganic constituents, organic compounds, and bacteria in water from selected wells and springs from the southern boundary of the Idaho National Engineering Laboratory to the Hagerman area, Idaho: U.S. Geological Survey Open-File Report 92-91 (DOE/ID 22102), $42 \mathrm{p}$.

Claassen, H.C., 1982, Guidelines and techniques for obtaining water samples that accurately represent the water chemistly of an aquifer: U.S. Geological Survey Open-File Report 82-1024, 49 p.

Currie, L.A., 1984, Lower limits of detection-Definition and elaboration of a proposed position for radiological effluent and environmental measurements: U.S. Nuclear Regulatory Commission NUREG/CR-4007, $139 \mathrm{p}$.

Fishman, M.J., and Friedman, L.C., eds., 1989, Methods for determination of inorganic substances in water and fluvial sediments: U.S. Geological Survey Techniques of Water-Resources Investigations, book 5, chap. A1, $545 \mathrm{p}$.

Friedman, L.C., and Erdmann, D.E., 1982, Quality assurance practices for the chemical and biological analyses of water and fluvial sediments: U.S. Geological Survey Techniques of Water-Resources Investigations, book 5, chap. A6, $181 \mathrm{p}$. 
Garabedian, S.P., 1986, Application of a parameter-estimation technique to modeling the regional aquifer underlying the eastern Snake River Plain, Idaho: U.S. Geological Survey Water-Supply Paper 2278, $60 \mathrm{p}$.

Goerlitz, D.F., and Brown, Eugene, 1972, Methods for analysis of organic substances in water: U.S. Geological Survey Techniques of Water-Resources Investigations, book 5, chap. A3, $40 p$

Haglund, D.S., 1972, Uranium-Element and geochemistry, in Fairbridge, R.W., ed., The Encyclopedia of Geochemistry and Environmental Sciences: Stroudsberg, Pa., Dowden, Hutchinson, and Ross, 1,321 p.

Hardy, M.A., Leahy, P.P., and Alky, W.M., 1989, Well installation and documentation, and ground-water sampling protocols for the pilot National Water-Quality Assessment Program: U.S. Geological Survey Open-File Report 89-396, 36 p.

Idaho Department of Health and Welfare, 1989, Idaho regulations for public drinking water systems: Boise, Rules and Regulations of the Department of Health and Welfare, title 1, chapter 8 , not paginated.

Jones, B.E., 1987, Quality control manual of the U.S. Geological Survey's National Water Quality Laboratory: U.S. Geological Survey Open-File Report 87-457, 17 p.

Kretz, Ralph, 1972, Potassium-Element and geochemistry, in Fairbridge, R.W., ed., The Encyclopedia of Geochemistry and Environmental Sciences: Stroudsberg, $\mathrm{Pa}$., Dowden, Hutchinson, and Ross, 1,321 p.

Mann, L.J., 1986, Hydraulic properties of rock units and chemical quality of water for INEL-1--a 10,365-foot deep test hole drilled at the Idaho National Engineering Laboratory, Idaho: U.S. Geological Survey Water-Resources Investigations Report 86-4020 (DOE/ID-22070), 23 p.

-.-- 1989, Tritium concentrations in flow from selected springs that discharge to the Snake River, Twin FallsHagerman area, Idaho: U.S. Geological Survey Water-Resources Investigations Report 89-456 (DOE/ID-22084), $20 \mathrm{p}$

Mann, L.J., and Cecil, L.D., 1990, Tritium in ground water at the Idaho National Engineering Laboratory, Idaho: U.S. Geological Survey Water-Resources Investigations Report 90-4090 (DOE/ID-22090), 35 p.

Mann, L.J., and Knobel, L.L., 1990, Radionuclides, metals, and organic compounds in water, eastern part of A\&B Irrigation District, Minidoka County, Idaho: U.S. Geological Survey Open-File Report 90-191 (DOE/ID-22087), $36 \mathrm{p}$.

Orr, B.R., Cecil, L.D., and Knobel, L.L., 1991, Background concentrations of selected radionuclides, organic compounds, and chemical constituents in ground water in the vicinity of the Idaho National Engineering Laboratory: U.S. Geological Survey Water-Resources Investigations Report 91-4015 (DOE/ID-22094), $52 \mathrm{p}$.

Pittman, J.R., Jensen, R.G., and Fischer, P.R., 1988, Hydrologic conditions at the Idaho National Engineering Laboratory, 1982-1985: U.S.Geological Survey Water-Resources Investigations Report 89-4008 (DOE/ID-22078), $73 \mathrm{p}$.

Pritt, J.W., 1989, Quality assurance of sample containers and preservatives at the U.S. Geological Survey National Water Quality Laboratory, in Pederson, G.L., and Smith, M.M., compilers, U.S. Geological Survey Second National Symposium on Water Quality - Abstracts of the technical sessions, November 12-17,1989: Orlando, Fla., U.S. Geological Survey Open-File Report 89-409, 111 p.

Pritt, Jeffery, and Jones, B.E., eds., 1989, 1990 National Water Quality Laboratory services catalog: U.S. Geological Survey Open-File Report 89-386, parts 1-5.

Stevens, H.H., Jr., Ficke, J.F., and Smoot, G.F., 1975, Water temperature--influential factors, field measurement, and data presentation: U.S. Geological Survey Techniques of Water-Resources Investigations, book 5, chap. D1, $65 \mathrm{p}$. 
Thatcher, L.L., Janzer, V.J., and Edwards, K.W., 1977, Methods for determination of radioactive substances in water and fluvial sediments: U.S. Geological Survey Techniques of Water-Resources Investigations, book 5, chap. A5, 95 p.

U.S. Environmental Protection Agency, 1987, Annual Report, Fiscal Year 1986--Methods Validation Report (radiation): U.S. Environmental Protection Agency Report No. EPA/600/x-87/128, 55 p.

-..-- 1989, Protection of Environment, Code of Federal Regulations 40: Office of the Federal Register, National Archives and Records Administration, parts 100 to $149,948 \mathrm{p}$.

....- 1990a, Fact Sheet, Drinking water regulations under the Safe Drinking Water Act: U.S. Environmental Protection Agency Office of Drinking Water, $43 \mathrm{p}$.

..... 1990b, Fact Sheet, Proposed national primary drinking water regulations for 24 contaminants: U.S. Environmental Protection Agency Office of Drinking Water, $14 \mathrm{p}$.

...-. 1991, National primary drinking water regulations; radionuclides; proposed rule: Federal Register, v. 56, no. 138, p. $33050-33127$.

Wegner, S.J., 1989, Selected water quality assurance data for water samples collected by the U.S. Geological Survey, Idaho National Engineering Laboratory, Idaho, 1980 to 1988: U.S. Geological Survey WaterResources Investigations Report 89-4168 (DOE/ID-22085), 91 p.

Wegner, S.J., and Campbell, L.J., 1991, Radionuclides, chemical constituents, and organic compounds in water from designated wells and springs from the southern boundary of the Idaho National Engineering Laboratory to the Hagerman area, Idaho, 1989: U.S. Geological Survey Open-File Report 91-232 (DOE/ID-22098), $49 \mathrm{p}$.

Wershaw, R.L., Fishman, M.J., Grabbe, R.R., and Lowe, L.E., 1987, Methods for the determination of organic substances in water and fluvial sediments: U.S. Geological Survey Techniques of Water-Resources Investigations, book 5, chap. A3, 80 p.

Whitehead, R.L, 1986, Geohydrologic framework of the Snake River Plain, Idaho and eastern Oregon: U.S. Geological Survey Hydrologic Investigations Atlas HA-681, 3 sheets, scale 1:1,000,000,

Wood, W.W., 1981, Guidelines for collection and field analysis of ground-water samples for selected unstable constituents: U.S. Geological Survey Techniques of Water-Resources Investigations, book 1, chap. D2, $24 \mathrm{p}$. 

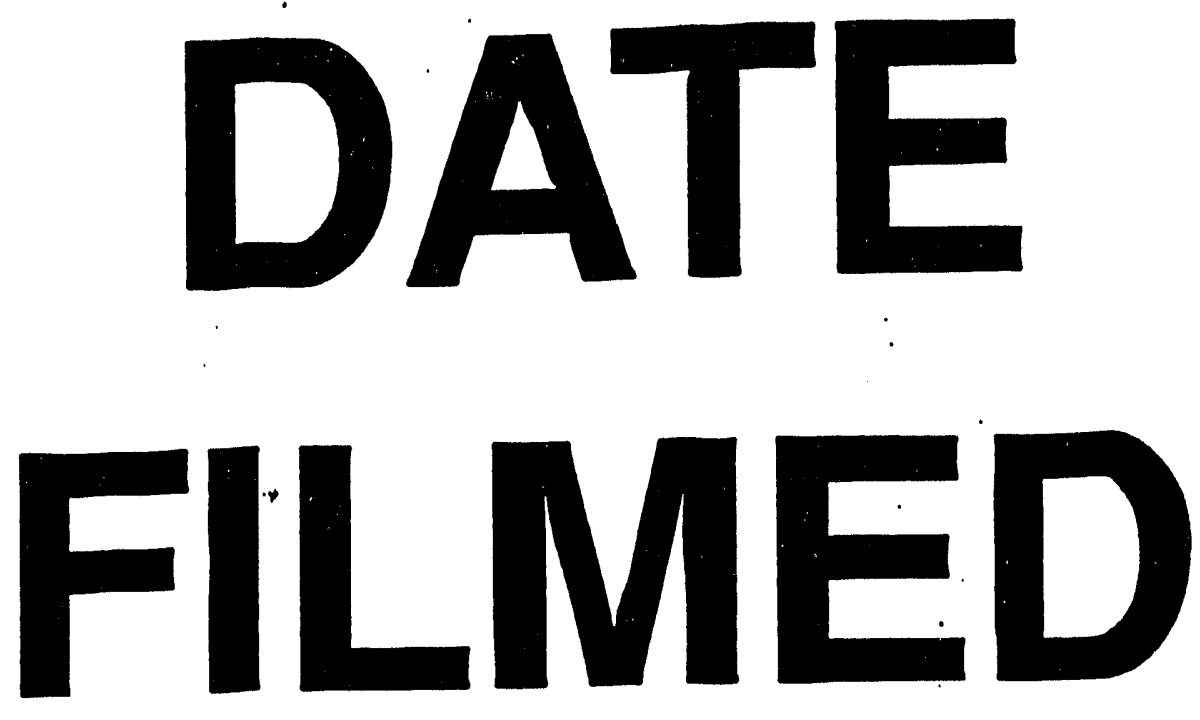

$1 / 10 / 94$
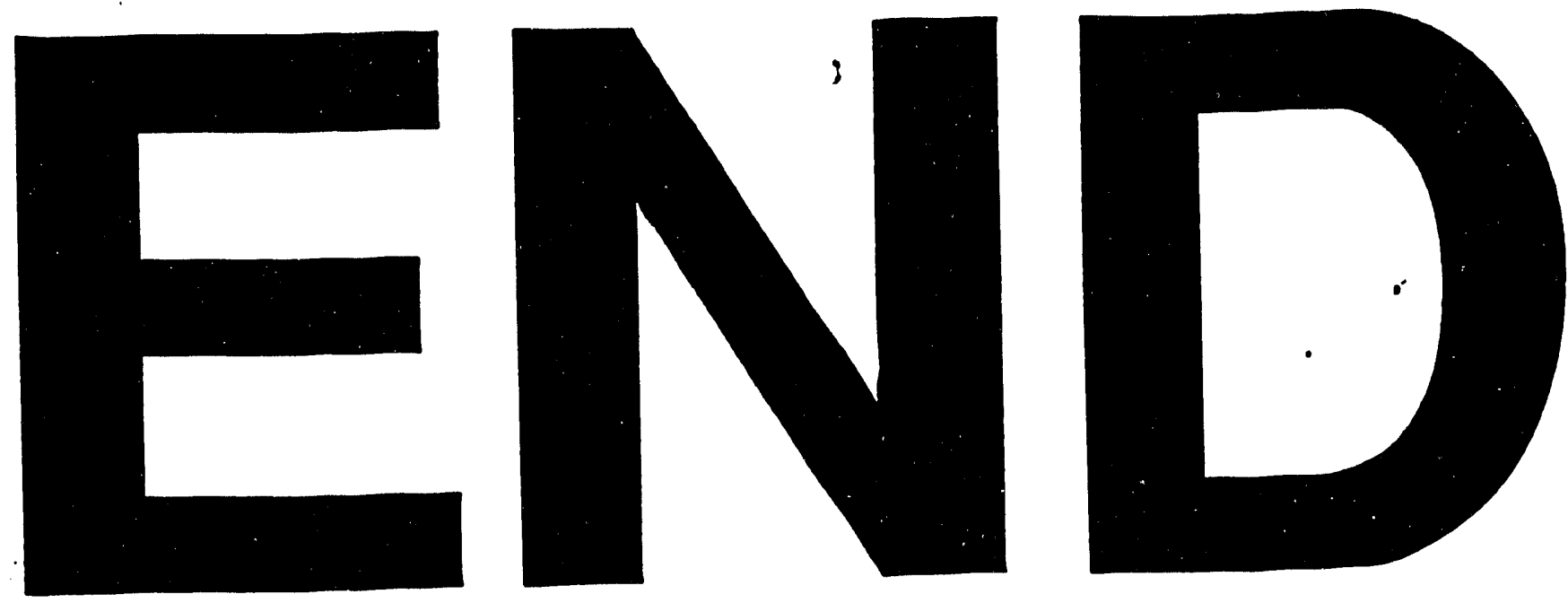
